\title{
SOBRE LA SECUENCIA CERÁMICA DEL PERÍODO FORMATIVO DE TARAPACÁ (900 A.C.-900 D.C.): ESTUDIOS EN PIRCAS, CASERONES, GUATACONDO Y RAMADITAS, NORTE DE CHILE
}

\author{
ABOUT THE CERAMIC SEQUENCE OF THE FORMATIVE PERIOD IN \\ TARAPACÁ (BC 900-900 AD): STUDIES IN PIRCAS, CASERONES, \\ GUATACONDO AND RAMADITAS, NORTHERN CHILE
}

\author{
Mauricio Uribe Rodríguez ${ }^{1}$ y Estefanía Vidal Montero ${ }^{1}$
}

\begin{abstract}
Este artículo expone el estudio del material cerámico de las recolecciones de superficie y excavaciones realizadas en los sitios Pircas, Caserones, Guatacondo y Ramaditas, correspondientes a asentamientos claves del período Formativo de las quebradas de Tarapacá y Guatacondo. Su relevancia radica en que estos poblados ejemplifican parte de los procesos de complejidad y evolución social que se experimentaron en los Valles Occidentales de los Andes Centro Sur. De este modo, se presenta la clasificación del material doméstico de acuerdo a una tipología ya probada para la región y se evalúa su comportamiento cuantitativo, temporal y funcional. El propósito es ofrecer una secuencia cerámica que permita abordar el proceso formativo regional y entregar información complementaria a otras materialidades conspicuas del período. A partir de estos resultados, compartimos nuestras reflexiones acerca del proceso de evolución que se infiere desde el uso de la alfarería, proponiendo tres posibles situaciones o escenarios de complejidad social que se desarrollarían diacrónica y sincrónicamente durante el Formativo Temprano y Tardío e inicios del Intermedio Tardío en el territorio comprendido por la Pampa del Tamarugal y la costa asociada.
\end{abstract}

Palabras claves: análisis cerámico, período Formativo, Tarapacá, evolución y complejidad social, Andes Centro Sur.

This paper presents the analysis of pottery from surface collections and excavations at the sites of Pircas, Caserones, Guatacondo and Ramaditas, corresponding to key settlements of the Formative Period in the Tarapaca and Guatacondo ravines. These sites are notable in that they exemplify processes of social complexity and evolution experienced by the people inhabiting the Western Valleys of the South Central Andes. We present the classification of household materials using a known typology for this region and examine it quantitatively, chronologically and functionally.. Our purpose is to offer a ceramic sequence that provides an approach to the regional Formative process and to present complementary information for use with other materials from this period. With these results, we share our ideas about ceramic analysis, the uses of pottery and social evolution, and propose three probable situations or scenarios of increasing social complexity that took place diachronically and synchronically over the course of nearly two thousand years. Consequently, our study offers an empirical basis for future and deeper investigations of the Early and Late Formative periods and the beginning of the Late Intermediate Period in the Pampa del Tamarugal and coast of Tarapacá.

Key words: Pottery analysis, Formative Period, Tarapacá, social complexity, South Central Andes.

Hasta ahora ha prevalecido el criterio funerario para postular y rotular a los complejos episodios agrarios iniciales. No obstante, queda fuera de duda que antes de definir un modelo explicativo debidamente contrastado se requiere una rigurosa factografía de la actividad residencial, donde el objetivo holístico es más implícito (Núñez 1984a:166).

Retomando el llamado de atención hecho por Núñez hace más de dos décadas, este artículo ofrece un estudio sistemático y actualizado del material cerámico de los sitios arqueológicos Pircas, Caserones, Guatacondo y Ramaditas, correspondientes a asentamientos paradigmáticos del período Formativo de las quebradas de Tarapacá y Guatacondo, en la subárea de Valles Occidentales de los Andes Centro Sur (Figura 1). Sin duda, han sido notables los avances de esta temática en las regiones culturales de Arica, el río Loa y San Pedro de Atacama (p.ej., Muñoz 2004, 2005; Sinclaire 2004; Sinclaire et al. 1998; Uribe 2006); sin embargo, las

1 Departamento de Antropología, Facultad de Ciencias Sociales, Universidad de Chile, Santiago, Chile. mur@ uchile.cl; estefania. vidal.montero@gmail.com 


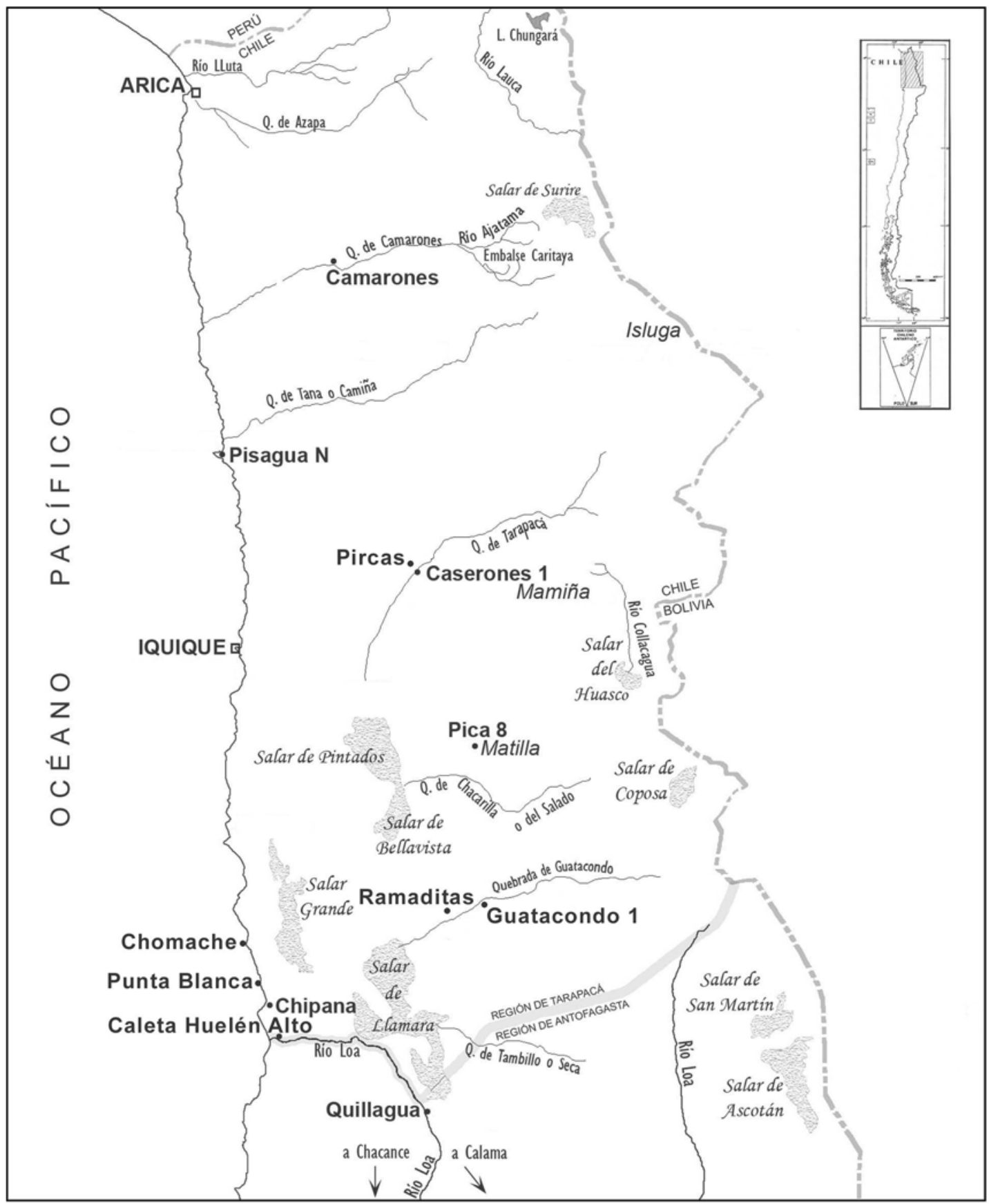

Figura 1. Mapa de la región y principales sitios mencionados en el texto (dibujo de P. Chávez).

Map of the region and sites mentioned in the text (drawn by P. Chávez).

investigaciones en la región de Tarapacá, enmarcada entre las quebradas de Camarones y el Loa, han sido todavía escasas e intermitentes (Mavrakis 1985; Núñez y Moragas 1983; Núñez y Santoro 2011; Rivera 1988-89). Esta situación implica una falencia que ha dificultado alcanzar una comprensión más acabada de la prehistoria regional, especialmente si esta etapa se considera como fundamental para abordar la evolución de la complejidad social de la vertiente occidental de los Andes Centro Sur. Lo que, por otra parte, es elocuente en el notable desarrollo del sistema de asentamiento que caracteriza a 
Tarapacá en dichos momentos como una expresión reveladora de transformaciones sociales (Adán et al. 2007; Núñez 1982a, 1984a, 2006; Núñez y Santoro 2011; Rivera 2005; Rivera et al. 1995-96). De hecho, desde las primeras investigaciones de Uhle (1922), Latcham (1938), Bird (1943) y Schaedel y Munizaga (1957), se planteó que en la zona y particularmente en su costa existirían las primeras expresiones de esta innovación tecnológica, donde la alfarería acompañaría los cambios observados en la arquitectura.

En consecuencia, aunque sabiendo que la cerámica entrega una información muy parcial de la realidad pasada (Lumbreras 2006), nos interesa compartir nuestro estudio puesto que es un elemento que se asocia al proceso de evolución social y que contiene información valiosa sobre el mismo, no exclusiva pero sí complementaria a los datos ofrecidos por el resto de la materialidad arqueológica que destaca durante el Formativo (p.ej., arquitectura, agricultura, textilería y metalurgia). En primer lugar, porque aclara el marco histórico cultural donde se desarrolló el Formativo; y, segundo, porque al centrarse en el ámbito doméstico, inédito hasta el momento, no sólo permite superar la arqueología funeraria característica de este período y de la región (Muñoz 1989; Núñez 1984a), sino que además provee de información vital para abordar prácticas económicas y sociales que nos interesan conocer. En este sentido, intentamos superar la vieja polémica sobre los orígenes generada por la definición de las fases Azapa, Faldas del Morro y Alto Ramírez (Dauelsberg 1985; Muñoz 1983; Núñez 1969; Rivera 1994; Santoro 1980, 1981, 2000), aportando a la identificación de la mayor diversidad de situaciones que ofrece el Formativo y plantear modos alternativos de evolución sociopolítica que se gestaron más allá de los Andes Centrales y los tradicionales modelos de verticalidad de los Andes Centro Sur (p.ej., Núñez y Dillehay 1975[1979]). De este modo, pretendemos reflexionar sobre las consecuencias del acceso y uso de la alfarería para avanzar en la comprensión de los procesos de complejidad social que experimentaron las poblaciones de la Pampa del Tamarugal y su costa entre 900 a.C. y 900 d.C.

\section{Algunos Antecedentes Sobre la Cerámica y el Formativo de Tarapacá}

Núñez y Moragas (1983) han sido de los pocos en desarrollar trabajos especializados sobre la cerámica del territorio tarapaqueño. En particular, destacamos su estudio sobre la alfarería temprana del asentamiento costero Cáñamo al sur de Iquique, el cual intenta esclarecer a través de una tipología las relaciones entre la aparición de la cerámica, la agricultura inicial y el desarrollo de las redes de intercambio a larga distancia para entender la complejidad social que fue adquiriendo este proceso (fase Cáñamo II o Montículo). En general, su análisis combina la clásica descripción arqueológica con análisis petrográficos de las muestras, los que además fueron comparados con una evaluación geológica del lugar en estudio. No obstante, se aprecia una importante arbitrariedad en la documentación de los datos (p.ej., estratigráficos y frecuencias), así como falta de claridad en la descripción que inciden en una difícil representación de los tipos cerámicos y su comportamiento contextual, aparte de necesitar mayor apoyo de fechados absolutos. La totalidad del material referiría a alfarería de uso doméstico, se supone que para cocina (tipos Cáñamo Alisado Homogéneo e Imperfecto), seguramente de producción familiar, donde las ollas alisadas serían mayoritarias $(67,24 \%)$; mientras que los tipos Cáñamo Estriado y Paleteado serían bastante minoritarios, al igual que los Café Pulidos. Esto es relacionado con la concentración de la cerámica alisada en los primeros estratos, fechados por radiocarbono y termoluminiscencia entre 860 y 810 a.C. (dataciones no calibradas), señalando una ocupación del Formativo Temprano sobre otra del Arcaico Tardío donde se insertarían los primeros fragmentos alisados, y culminando en la superficie con la presencia de alfarería pulida (Núñez y Moragas 1983; Moragas 1995).

Así, para los autores, una de las primeras tradiciones cerámicas que llegó a la costa desértica del norte chileno fue la café alisada, proveniente de alguna población relacionada con la cultura Wankarani de Bolivia o grupos emparentados, cuya tecnología fue adoptada plenamente por las poblaciones marítimas de Chile ya sea por contacto directo o indirecto con las comunidades altiplánicas. No obstante, a partir de los mismos análisis realizados, es posible discutir estos supuestos pues parece contradictorio que al mismo tiempo que se propone un ingreso altiplánico, se considere a toda esta alfarería como parte de "una sola familia cerámica” (Núñez y Moragas 1983:48), sugiriendo también un origen local para ella. Según sus resultados, los tipos alisados mostrarían materias primas claramente costeras, mientras que los 
estriados y pulidos presentarían componentes tanto volcánicos del interior como mixtos; sin embargo, esto también sugiere que desde temprano el radio de movilidad pudo haberse restringido al litoral y las quebradas bajas de la Pampa del Tamarugal, sin tener que acceder o contactarse necesariamente con el altiplano. Además, la alfarería con componentes interiores puede estar reflejando una ocupación posterior, relacionada con los tipos formativos tardíos e incluso del desarrollo regional preincaico (complejo Pica Tarapacá), donde predominan los estriados o rasmillados (Uribe et al. 2007).

En esta misma dirección han sido consideradas las evidencias formativas de la desembocadura del Loa, si bien mayormente relacionadas con las manifestaciones funerarias y en particular con los túmulos de Caleta Huelén (Moragas 1995; Núñez 1971; Spahni 1967). Para los sitios denominados Caleta Huelén-7, 10, 20 y 43, fechados entre 450 a.C. y 820 d.C. (radiocarbono no calibrado), también se documenta la presencia de cerámica correspondiente a ejemplares monocromos alisados, burdos y pulidos rojos, negros y grises, en gran parte concentrados alrededor de 215 d.C. (Tartaglia 1980). Los contextos en su mayoría tendrían un carácter marítimo, reconociéndose que la introducción de elementos del interior sería muy menor; no obstante, se insiste en la existencia de rasgos altiplánicos (p.ej., cobre, maíz y quínoa), cuya presencia sería el producto de desplazamientos poblacionales desde el interior por los cursos fluviales hacia la costa arreica a modo de "corredores", donde las mismas expresiones serían muy escasas o nulas al alejarse de tales cuencas (Moragas 1995:70; Núñez y Santoro 2011) ${ }^{1}$. Una situación casi idéntica se repite para el litoral norte de la región de acuerdo a la definición de un Grupo II, especialmente identificado en Punta Pichalo (Rivera 1988-89), también en Camarones e incluso en Alto Ramírez de Arica. Así, se constituiría una técnica avanzada, en oposición a otra (Grupo I) considerada experimental e imperfecta derivada de los últimos momentos de la cultura Chinchorro, lo que vincularía al Grupo II con lo andino por cierta familiaridad con la alfarería temprana en general y Chiripa de Bolivia en particular. En este caso, se propone que estas dos técnicas de orígenes distintos o "tradiciones ceramológicas diferentes" (Rivera 1988-89:102) convivirían para posteriormente permitir un desarrollo más complejo en términos económicos e ideológicos que se conectaba con el altiplano.
Esta alfarería costera, tanto doméstica como funeraria, mantendría vínculos claros con el sitio Aldea de Caserones o Caserones 1 por la presencia de componentes cerámicos similares (Núñez 1966, 1982a), de tipos alisados y pulidos sin asas ni decoración, principalmente de origen local, aunque también se suponía una génesis foránea para la alfarería pulida (Mavrakis 1985; True 1980). A esto se suma el análisis de Kautz y colaboradores (1980), el único estudio para el norte de Chile que hasta ese momento había experimentado con técnicas fisicoquímicas de alta precisión aplicadas a la cerámica, quienes sometieron a evaluación la clasificación de Caserones. De acuerdo con ésta, se proponía la existencia de cinco a seis clases cerámicas dentro de una tradición, las cuales proveían información acerca de los movimientos poblacionales, los contactos y las influencias culturales ocurridas a lo largo de su ocupación. Según Núñez (1965), la cerámica permitía distinguir que dentro de una alfarería mayoritariamente local se introducían algunos elementos foráneos, en particular cerámica negra pulida vinculada con San Pedro de Atacama, apoyando la idea de un sistema de verticalidad asociado al tráfico de caravanas.

Con el objetivo de evaluar estas inferencias, se sometieron 12 muestras de esos tipos al análisis de dispersión de rayos X, gracias a lo cual se pudo concluir preliminarmente que las muestras de Caserones tenían un origen común y eran distintas a las de San Pedro $^{2}$. Esto no significaba que toda la alfarería era igual, pero sí que su materia prima provenía de la misma localidad y con ello se cuestionaban las conexiones a tan larga distancia.

Complementariamente, a pesar de ser bastante cualitativas, también nos parecen muy interesantes las apreciaciones de Mavrakis (1985), quien a partir de su análisis tipológico y estratigráfico intentó demostrar la existencia de un creciente proceso de complejidad social en Caserones. Durante esos momentos, coincidentemente con los trabajos de True (1980), aprecia la predominancia de tipos alisados, pulidos y engobados, especialmente en las capas intermedias e inferiores, dando paso entre 600 y 800 d.C. al período IV con muy poca cerámica pulida y un considerable aumento de los alisados hacia la superficie, donde los tipos pulidos casi desaparecen. Dentro de este marco, la población local habría experimentado la jerarquización social a la par de la especialización económica en gran escala (Núñez 1982a), pero que por causas 
más internas que externas convertirían al sitio en un asentamiento de características casi urbanas (Mavrakis 1985). Sin embargo, desde una u otra perspectiva, nunca queda estrictamente claro cómo se vincula la alfarería con el crecimiento aldeano, el intercambio caravanero y la jerarquización social.

Una situación parecida se ha planteado para Guatacondo (G I) al sur de Tarapacá, así como en Ramaditas al oeste del anterior. Particularmente, en Guatacondo se ha descrito cerámica sin decoración con fechas iniciales de 420 a.C., perdurando hasta 1.175 d.C. (radiocarbono no calibrado), con pastas granulosas y arenosas, de no más de un centímetro de grosor, cocción irregular, cuyas superficies varían desde el alisado al pulido, a veces con labio engrosado en coma que refieren a ollas y jarros o cántaros sin asas (Mostny 1970; Meighan 1980). Las mismas piezas, sobre todo las espatuladas y algunas figurillas de arcilla $^{3}$, podrían aparecer hacia 806-755 cal. a.C. y permanecer hasta 90 a.C. (sin calibrar) en los asentamientos de Ramaditas (Rivera 1998-99; Rivera 2005). En este caso se infiere la existencia de un proceso previo a Tiwanaku, no centralizado, pero política e ideológicamente dependiente del área circunlacustre que se habría asentado aquí y operado a base del conocimiento hidráulico y agrícola, ejercido por la acción vinculada con elites religiosas locales y altiplánicas de Pukara, Chiripa o Wankarani: "Nuestras evidencias sugieren que el sistema agrícola [de Ramaditas] pudo haber sido introducido por colonizadores foráneos" (Rivera 2005:34).

Complementariamente, en el cementerio Tarapacá 40A y B con fechados absolutos calibrados entre 950 a.C. y 660 d.C. (Oakland 2000), se encontraron escasas vasijas a modo de cuencos y platos de color café, junto a una pieza restringida semipulida gris con pequeñas asas de suspensión y decoración punteada, las que podrían adscribirse a la fecha inicial y no posteriores al 20 d.C. En el cementerio Tarapacá 40B, un sector mejor conocido y más tardío (con otros fechados no calibrados de 290 y 360 d.C. [Núñez 1969]), la alfarería sigue siendo como la anterior pero más abundante, distinguiéndose una familia de cerámica café alisada compuesta por jarros y cántaros, además de otras piezas a modo de cuencos u ollas. Por otra parte, se diferencia una familia de cerámica gris, negra y roja pulida donde se integran vasos y tazones troncocónicos; acompañados por un grupo de piezas miniaturas no cocidas, al que también se integran tapas para pequeños contenedores de harinas y discos usados como platos, además de las figurillas ya aludidas (Núñez 1967-68; Núñez y Moragas 1983; True y Núñez 1971). También dentro de esta evidencia funeraria se pueden incluir las referencias a Pica-Quisma y Pica-Tenencia del oasis homónimo (Moragas 1995; Sanhueza 2005), cuyas expresiones todavía son muy escasas o poco conocidas, pero interesantes porque se han interpretado desde dos perspectivas distintas abriendo el debate en relación con los modelos que han intentado explicar el Formativo de la región, tanto desde lo foráneo como de lo local. En el primer caso se mantiene la misma lectura ya reseñada que señala una penetración altiplánica que coloniza valles y oasis para luego pasar a la costa; mientras que en el segundo se realiza una evaluación más crítica que vuelve a valorizar el sustrato local y Arcaico, acercándose a los planteamientos aquí desarrollados.

En definitiva, por mucho tiempo la presencia de cerámica monocroma café, gris, negra y roja, alisada, pulida, espatulada o paleteada, a veces con bordes en coma y presencia de figurillas, ha sido aceptada como manifestación de un temprano proceso de difusión o expansión altiplánica entre el 800 y 900 a.C., alcanzando el litoral del Pacífico incluso antes del año 1.000 a.C. En particular, se concluyó que lo más parecido a la alfarería de sitios como Punta Pichalo, Cáñamo, Caserones, Guatacondo, Ramaditas y Caleta Huelén eran las cerámicas de Wankarani y las primeras expresiones de Chiripa, situación que se extendería por la costa tarapaqueña desde Camarones, Pisagua y el Loa hasta Cobija, intermediando los valles y oasis interiores asociados a la Pampa del Tamarugal (Aufderheide et al. 1994; Moragas 1982, 1995; Núñez 1966, 1967-68, 1970, 1971, 1982a, 1984a; Núñez y Moragas 1983; Rivera 1988-89, 2002, 2005). A algunas de estas manifestaciones, además, se agregarían elementos relacionados con San Pedro de Atacama e incluso del Noroeste Argentino (Núñez 1984b; Mavrakis 1985), pero siempre bajo una predominancia poblacional y una dependencia ideológica e incluso política con las tierras altas en general. Así, la evidencia cerámica alisada y pulida, aparte de otras características culturales, es concebida como expresión de una acotada diversidad de comunidades formativas cuyas fluctuaciones aludirían insistentemente a un flujo de población y movimientos expansivos desde los desarrollos altiplánicos. Estos, motivados por presiones demográficas y potenciando los valles u oasis intermedios de Tarapacá, accedieron a la 
costa, por donde se desplazaron longitudinalmente privilegiando los espacios agrícolas más ricos y enfrentando ajustes de adaptación al medio ambiente marítimo (Moragas 1995; Núñez 1971, 1982a). Dichos grupos se habrían instalado preferentemente en las desembocaduras, donde accederían a la riqueza marítima que, sobre una base de caza y recolección arcaica previa, los conminaría a quedarse de manera permanente. Bajo estas condiciones, se habría consolidado un modo de vida agromarítimo inicial, sustentable dentro de ciertas limitantes que, al crecer y debido a la dificultad de extender la agricultura en la costa arreica, tuvo su auge en el interior diferenciando factorías marítimas y "cabeceras" agrícolas en los valles, dando paso a un intenso escenario de intercambios (Núñez 1971:20).

\section{La Cerámica del Formativo de Tarapacá}

Sobre la base de nuestros recientes trabajos en Quillagua, Tarapacá y la costa de Iquique (Uribe 2009a, 2010; Uribe y Ayala 2004; Uribe et al. 2007), no nos resulta satisfactoria esta concepción que se ha mantenido vigente sobre el período Formativo de la región, razón por la cual deseamos contribuir a su discusión a través del análisis de la alfarería de los asentamientos que nos encontramos estudiando sistemáticamente en la Pampa del Tamarugal. En términos tipológicos, nos interesa avanzar en la descripción de sus distintas manifestaciones, tanto tempranas como tardías, ya que todavía es insuficiente lo que sabemos al respecto, sobre todo a partir de una escasa muestra y un limitado número de sitios no comparados entre sí. Y, de esta manera, completar la secuencia cerámica del Formativo que luego discutimos en términos estratigráficos y conductuales.

Actualmente reconocemos dos expresiones cerámicas para el Formativo de Tarapacá, sin mayores vinculaciones con el altiplano (Ayala y Uribe 2003; Ayala et al. 2008), destacando una alfarería inicial y otra más tardía (Uribe y Ayala 2004; Uribe 2009a). En primer lugar, hemos registrado cerámica con todas las características que se mencionan para una industria inicial de vasijas con "bordes en coma" (Figura 2); la cual hemos confirmado por termoluminiscencia como la más temprana con fechas de 730 y 530 a.C. en Quillagua, denominándola tipo Loa Café Alisado o LCA (Agüero et al. 2001, 2006; Uribe y Ayala 2004; Uribe 2006). Aunque muy ocasional, alcanza una amplia distribución espacial, relacionándose también con la alfarería inicial Alto Ramírez de los
Valles Occidentales y se reconoce con seguridad hasta las cabeceras del río Loa en la Circumpuna (Rivera 1988-89, 2002; Sinclaire et al. 1998; Uribe 2006); los que sin tratarse necesariamente de un mismo tipo, comparten pastas con desgrasante mineral y la misma solución técnica del engrosamiento del labio. Hasta ahora sabíamos que aparecía con $28 \%$ de frecuencia en Quillagua y alrededor de $1 \%$ en la quebrada de Tarapacá y costa de Iquique (Uribe 2009a, 2010; Uribe y Ayala 2004). Más específicamente, su pasta es de aspecto arenoso, densa en inclusiones blancas, redondeadas a angulares y de tamaño heterogéneo (selección mala a regular); en cambio, su composición petrográfica es muy homogénea y coherente con la geología local, constituida por líticos como granito de feldespato-potásico (K) y otros componentes cristalinos que incluyen cuarzo, feldespato-K y plagioclasa, posiblemente derivados de la fragmentación y/o erosión del granito de feldespato- $\mathrm{K}^{4}$. Su fractura es casi regular y bastante resistente, con escasos núcleos que indican un proceso regular y bien controlado de la cocción. Las superficies se hallan alisadas por ambas caras y es característica una textura rugosa en el cuello, cuyo color varía entre café y rojo claro (10YR 6/3, 7.5YR 6/4 y 6/6, 2.5YR 6/6) $)^{5}$, con escasas manchas de cocción. En algunos casos también se detectan huellas de pulimento en la cara externa que podrían deberse al desgaste por uso, así como es posible observar algunas manchas rojas derivadas de la aplicación de un engobe muy delgado y fugitivo. Por otro lado, los fragmentos de forma y en especial los puntos de inflexión (Figura 3) indican que se trata principalmente de vasijas restringidas con cuerpo ovoide, cuello hiperboloide y base convexa apuntada, bastante gruesas ( 6 a $9 \mathrm{~mm}$ de espesor) y de tamaños medianos a grandes de acuerdo al diámetro de su boca, casi siempre entre 10 y $20 \mathrm{~cm}$. Los bordes evertidos muestran labios convexos a rectos, con un notorio engrosamiento del labio (borde en coma). Ahora también sabemos que se incluyen vasijas no restringidas de cuerpo semiesférico, bordes directos y base convexa a plana (Figura 4), con un diámetro de boca bastante amplio, generalmente de 15 a $25 \mathrm{~cm}$, mientras que las bases no superan los $10 \mathrm{~cm}$. También les distingue un leve engrosamiento del labio, aunque adoptando un aspecto más recto que convexo. Ninguna de estas vasijas presenta asas, quizás porque su función fue resuelta por el engrosamiento de los bordes. Tampoco se observa decoración, salvo por el registro casual de inciso 

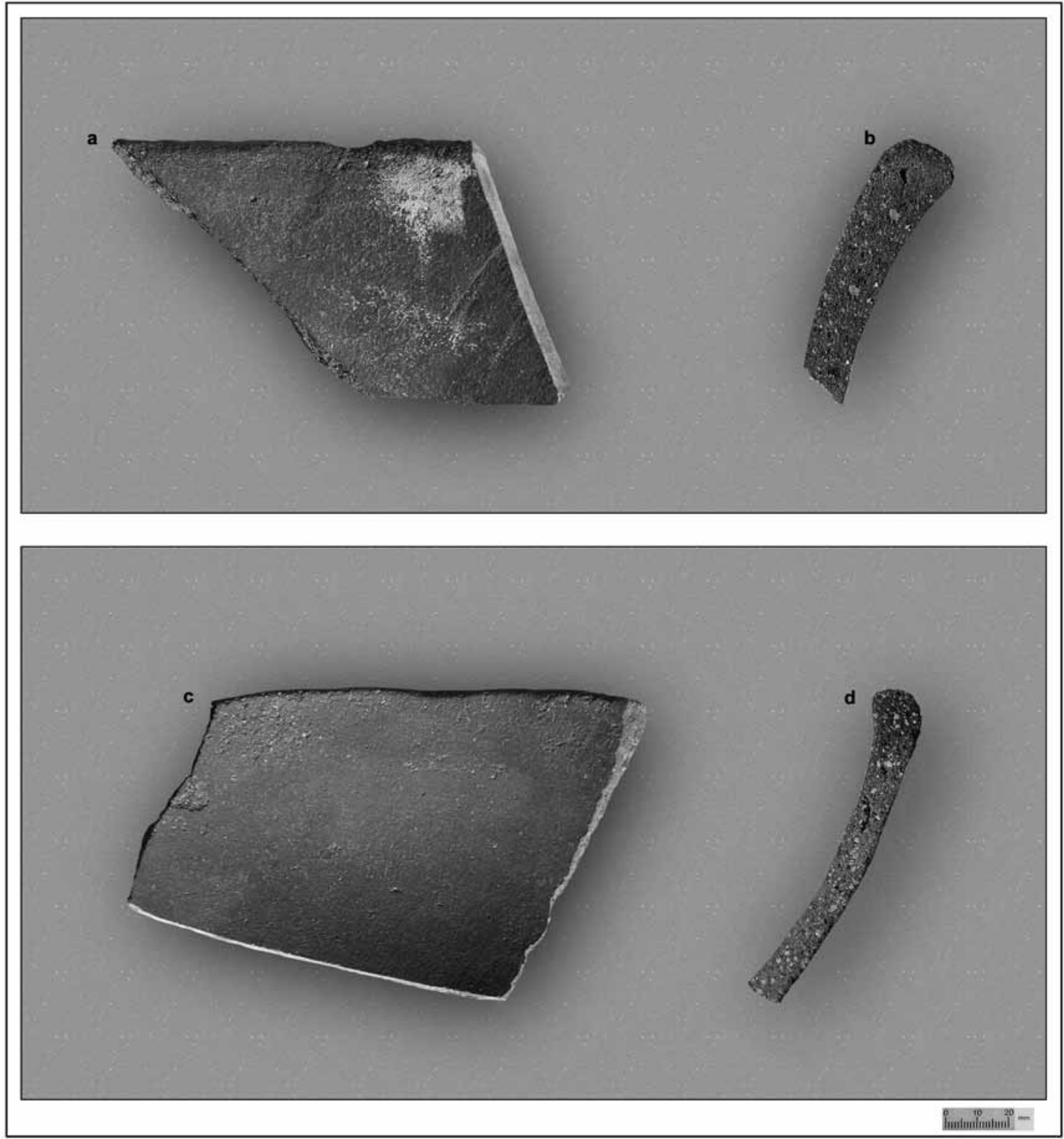

Figura 2. Tipo Loa Café Alisado (LCA), ejemplos de bordes de vasijas restringidas (a-b) y no restringidas (c-d). Examples of rims in restricted ( $a-b)$ and unrestricted $(c-d)$ vessels of the Loa Café Alisado (LCA) type.

punteado en el labio de algunas piezas pequeñas que hemos denominado Tarapacá Café Alisado Punteado o TCP (Uribe y Ayala 2004). Gallardo et al. (1991) informan fechas por termoluminiscencia de 220 y 270 d.C. para otros ejemplares de bordes en coma de Quillagua, sugiriendo un momento de contemporaneidad con la cerámica que pareciera popularizarse posterior a 200 d.C. y que constituye la segunda expresión que caracterizamos aquí.
Éste corresponde al tipo Quillagua Tarapacá Café Amarillento o QTC (10YR 7/3, 7/2 y 6/3, 2.5Y 6/2), que es predominante y se identifica principalmente en el cementerio Tarapacá 40B, pero también en Pica (Moragas 1995) y Quillagua donde alcanza 23\% de presencia, lo que asciende a $33 \%$ en Caserones y $23,45 \%$ en la costa de Iquique (Uribe 2009a; Uribe y Ayala 2004; Uribe et al. 2007). En general, tiene un aspecto tosco (Figura 5) y se caracteriza por pastas muy diversas en términos del color y la 


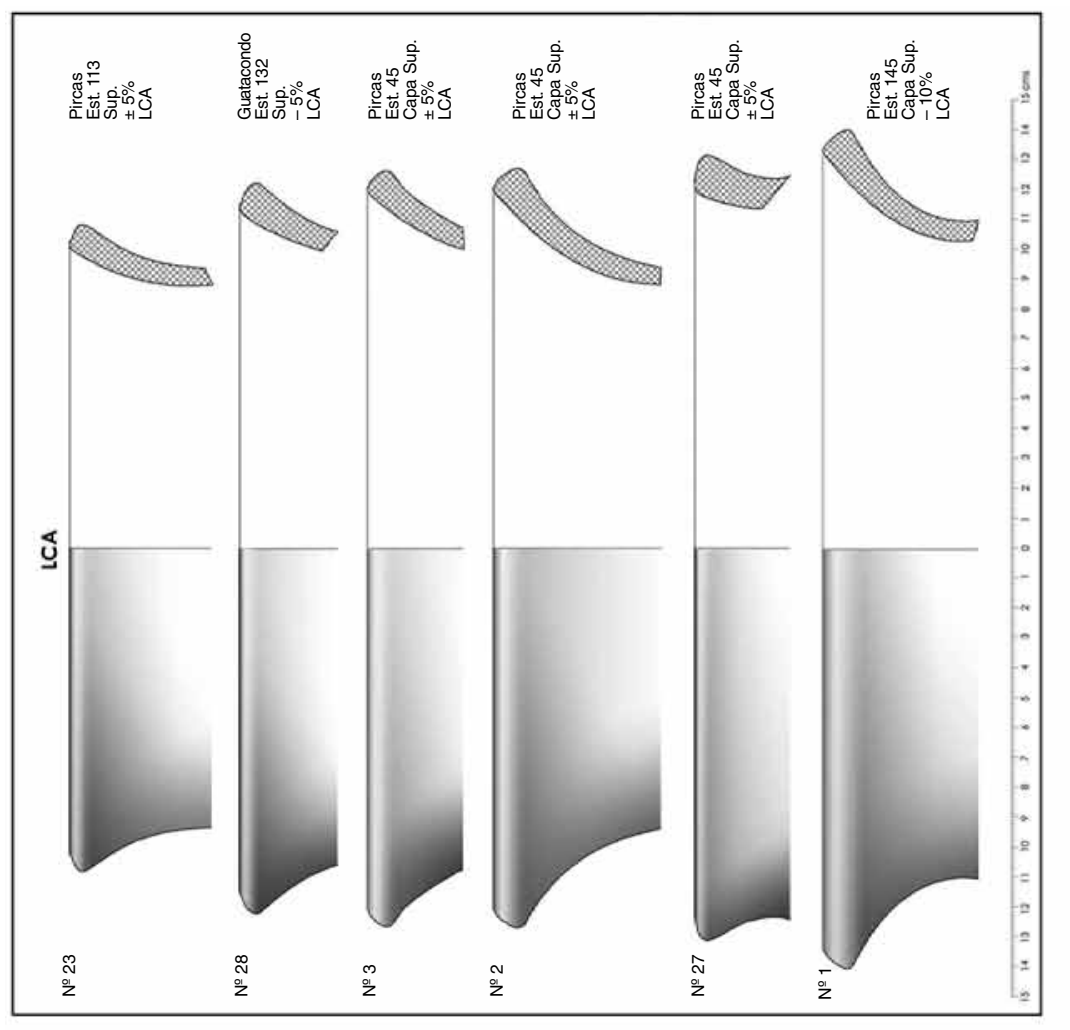

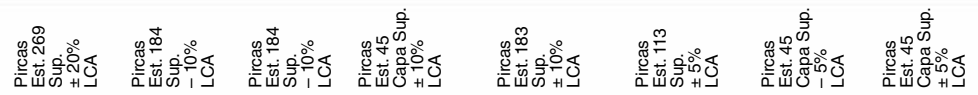
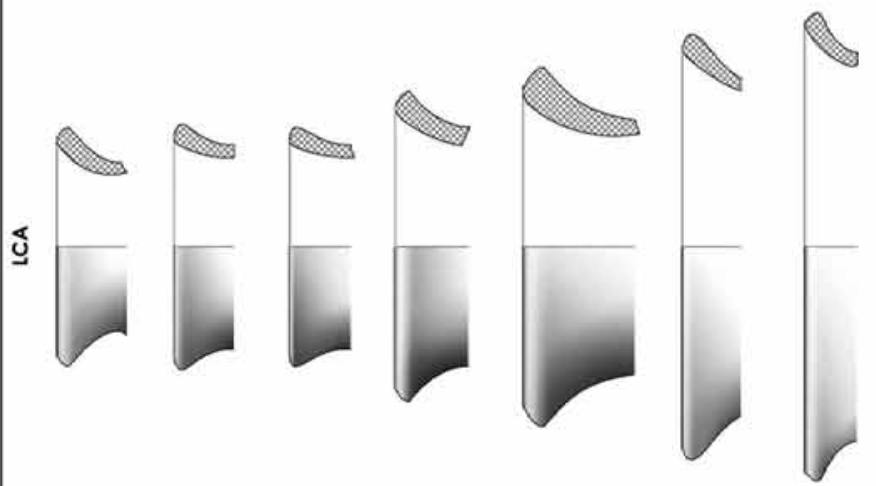

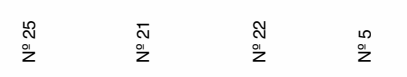

$\underset{\substack{N \\ z}}{\stackrel{2}{z}}$

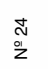

$\stackrel{0}{\check{2}}$

$\stackrel{+}{a}$

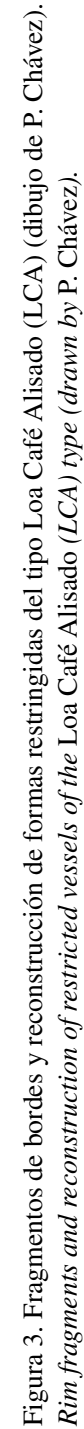



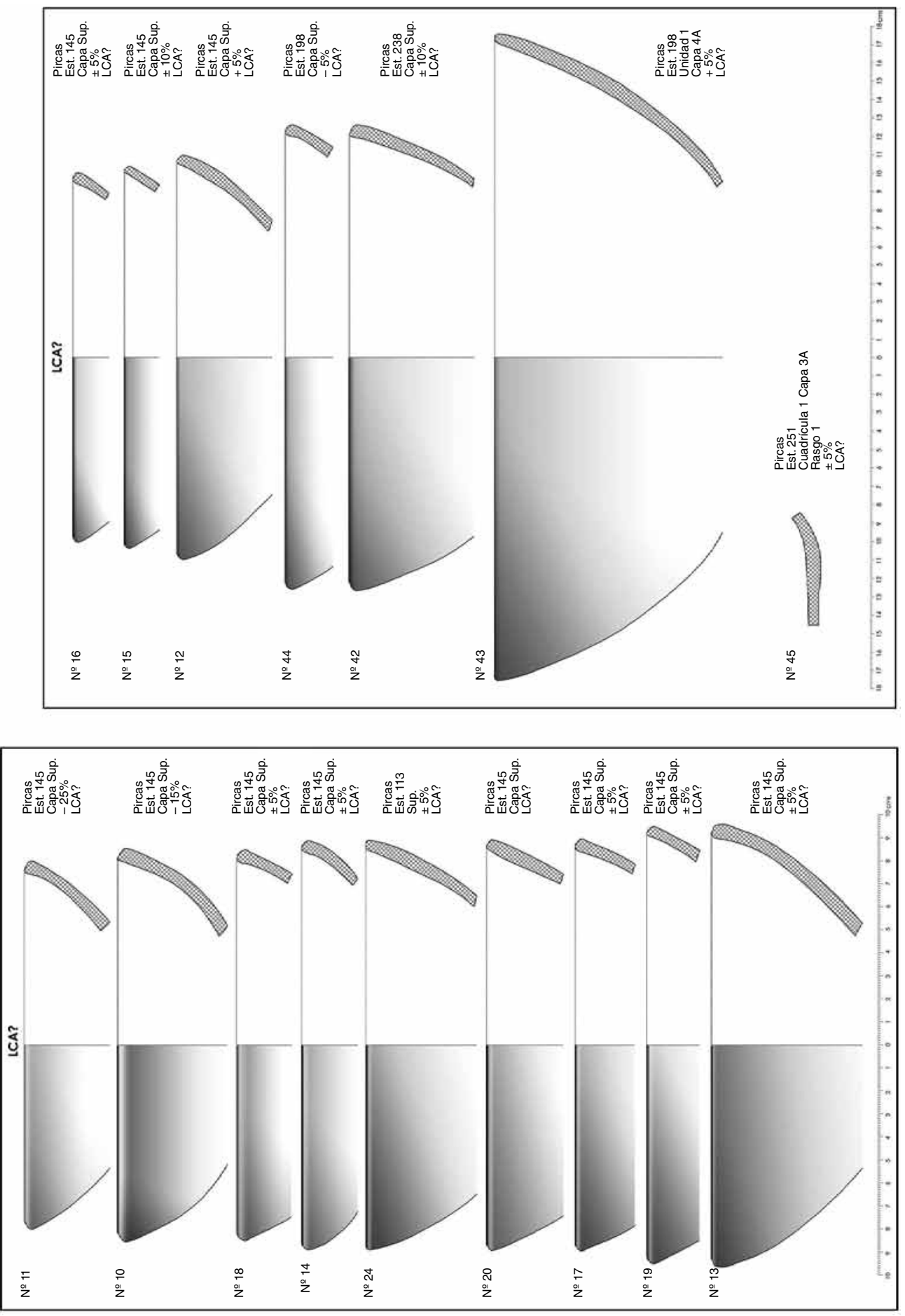


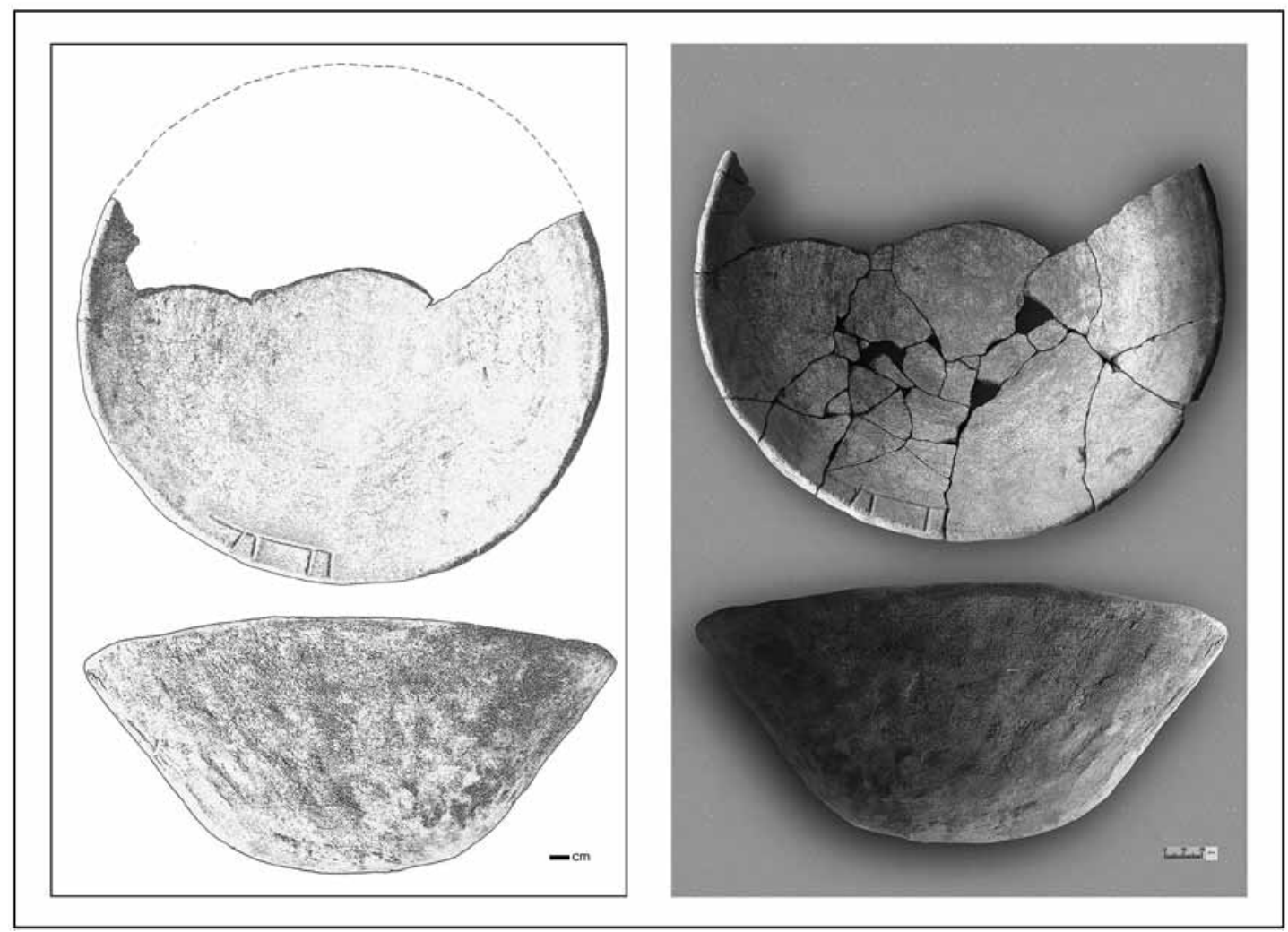

Figura 5. Tipo Quillagua Tarapacá Café Amarillento (QTC), ejemplo de vasijas no restringidas (dibujo de P. Chávez). Examples of unrestricted vessels of the Quillagua Tarapacá Café Amarillento (QTC) type (drawn by P. Chávez).

heterogeneidad de inclusiones (variando de mala a buena selección), donde se combinan minerales, restos orgánicos (p.ej., semillas de Prosopis) e incluso greda molida. A diferencia del tipo anterior, aunque de igual modo coincidente con la geología local, petrográficamente se pueden distinguir hasta cuatro grupos composicionales, destacando la combinación irregular de elementos líticos como granodiorita, lavas, calcedonias, metamórficos y/o vidrio, junto con cristales de cuarzo, plagioclasa, feldespato-K y/o piroxeno, en distintos estados y de orígenes tanto sedimentario como por posible fragmentación o erosión de andesitas o granitos. Se reconocen vasijas restringidas simples y no restringidas (Figuras 6 y 7), en su mayoría pequeños cuencos y tazones, a los que se agregan aquellos con una leve inflexión en el cuello a modo de pocillos, ollas o vasos altos ("floreros"). Las superficies fueron dejadas en estado de "cuero", mostrando el raspado o espatulado provocado por los instrumentos con que se construyeron, las huellas de los dedos del artesano e improntas de cestería en las bases (Figuras 8 y 9). También se distinguen variantes más locales que incluyen vasijas no restringidas como tazones o vasos y otras de cuerpo asimétrico con borde irregular terminado en vertedera que denominamos Quillagua Café Amarillento o QCA (Uribe y Ayala 2004). Complementariamente, se constata la fabricación de discos que funcionaron como tapas de las vasijas, las que fueron amarradas con fibras vegetales para asegurar sus contenidos (al parecer, granos, harinas y tubérculos), demostrando un uso como recipientes ceremoniales u ofrendas asociadas a alimentos cultivados en los cementerios conocidos (p.ej., Tarapacá 40B y Pica Quisma [Moragas 1995]). En este sentido, se trataría de tiestos cuyo destino fue doméstico y funerario (hasta ahora no detectado de manera elocuente en el caso del tipo LCA), como se desprende de las tumbas y túmulos de los cuales proviene mucho del material. Inclusive, muchas veces este empleo parece haber sido preeminente, pues la mayoría de las piezas son miniaturas (a veces no superiores a $2 \mathrm{~cm}$. de alto), carecen de tratamiento de superficie propiamente tal y muchas otras ni siquiera fueron cocidas o el proceso fue demasiado rápido, 


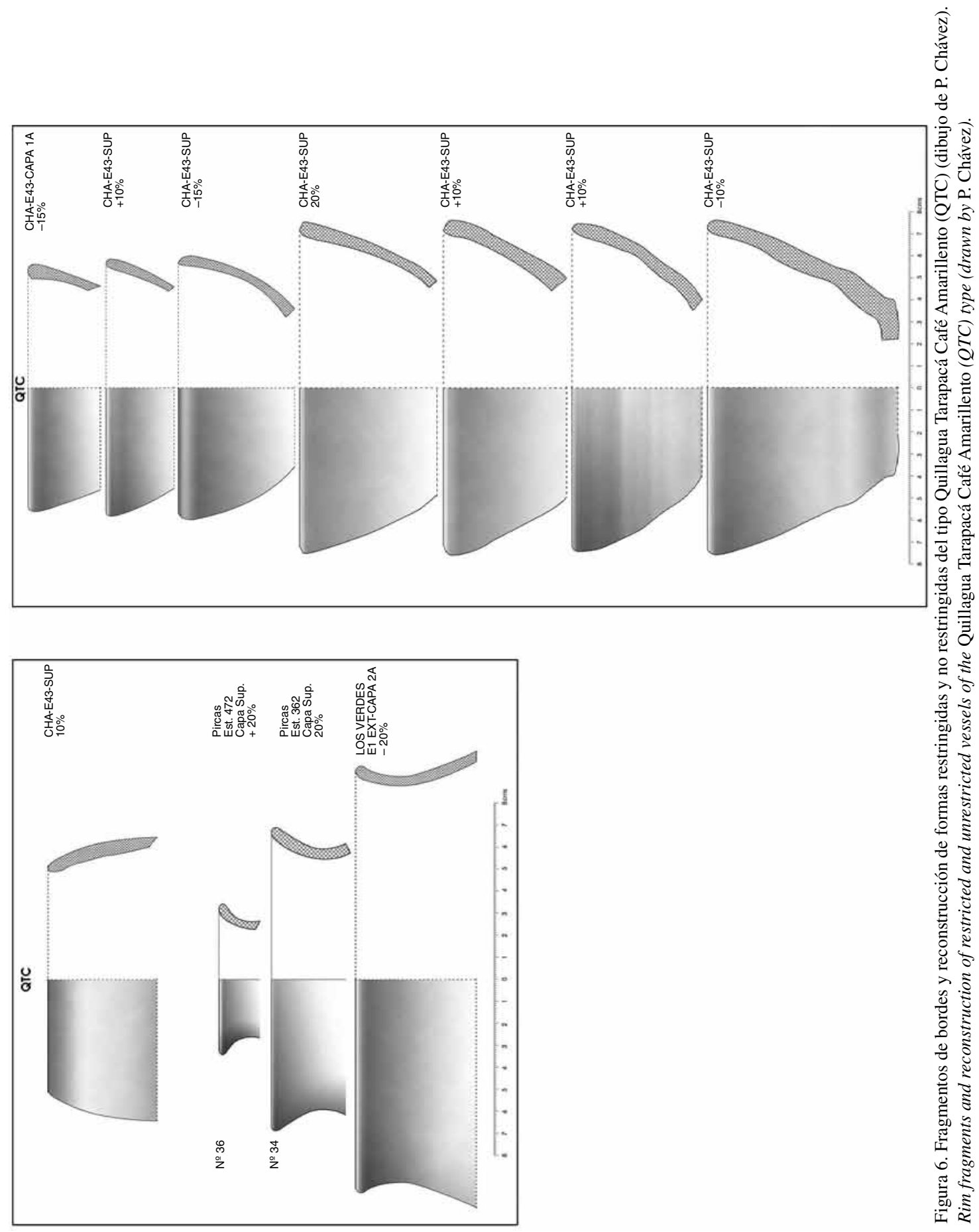




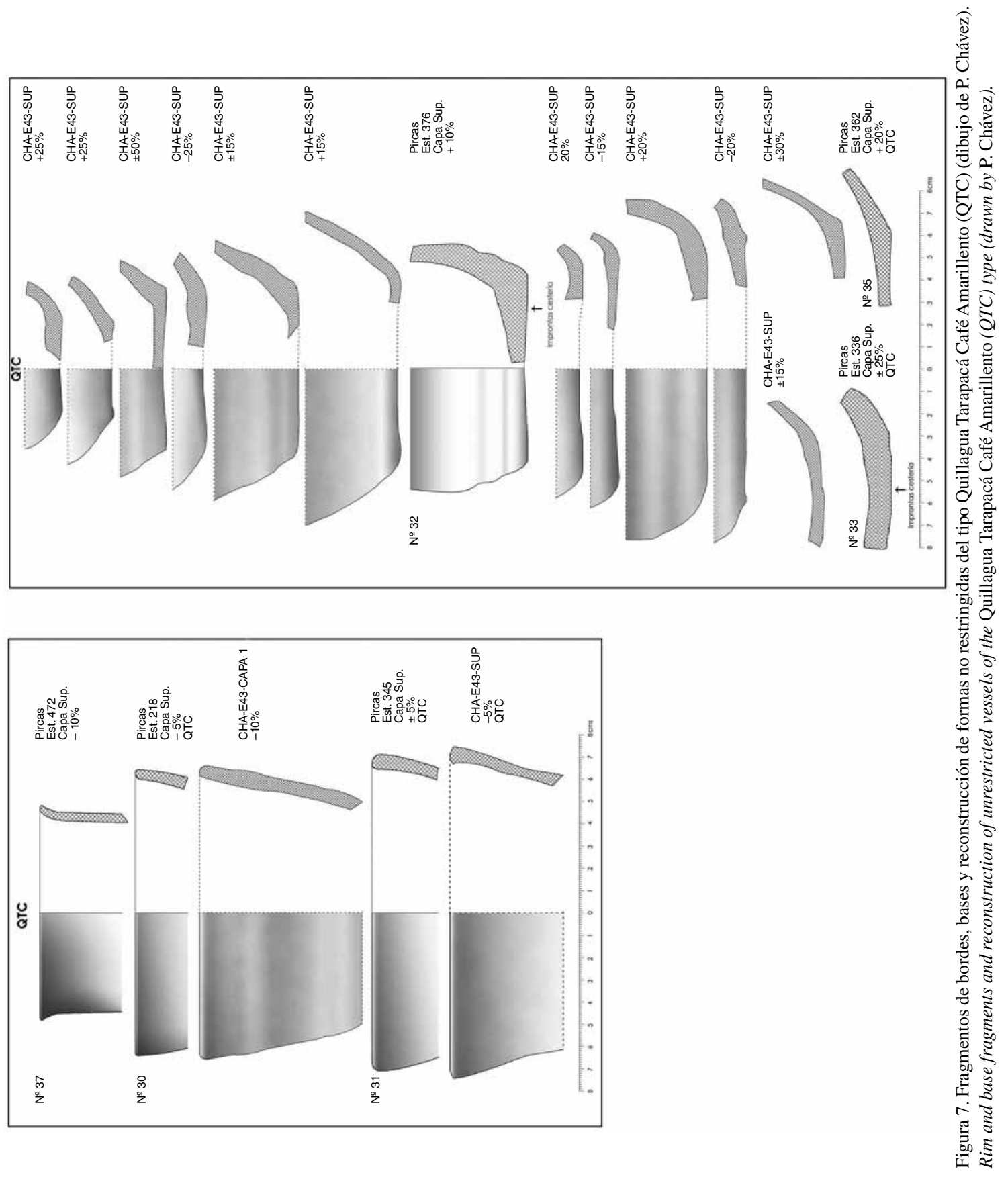


deficiente, muy irregular o incompleto, haciendo que las piezas sean frágiles y muy sensibles a la erosión ambiental.

A la anterior se suma la cerámica pulida del tipo Quillagua Rojo Pulido o QRP, la cual es escasa pero recurrente ya que, por ejemplo, sus frecuencias fluctúan desde $10 \%$ en Caserones, $4 \%$ en Quillagua y 2,63\% en la costa de Iquique (Uribe 2009a; Uribe y Ayala 2004; Uribe et al. 2007). Pensamos que constituye otra variedad de la alfarería tarapaqueña pues sus materias primas no son muy distintas, con una composición petrográfica muy parecida a la del tipo QTC (destacando la presencia de vidrio), aunque se trata de pastas más compactas y homogéneas, de cocción oxidante y fractura regular a angular. No obstante, tampoco se descarta de plano un vínculo foráneo relacionado con la cerámica pulida de Atacama que ocasionalmente aparece en la región (p.ej., piezas San Pedro Negro Pulido). Comprende formas no restringidas simples y complejas a modo de vasos troncocónicos y bordes inflectados con mamelones, así como vasijas restringidas correspondientes a botellas de cuerpo esférico y elíptico con cuello cilíndrico, hiperboloide o troncocónico, a veces también con mamelones en el cuello (Figura 10). Sin duda, esto es idéntico a lo observado en Caserones por True (1980) y Mavrakis (1985), si bien sus tonalidades varían de rojo a negro, distinguiéndose un grupo propio de piezas irrestrictas que adscribimos al tipo Caserones Negro Pulido (CNP) de estos autores.

Ambos tipos se remontarían a momentos tardíos del Formativo de acuerdo a los fechados de termoluminiscencia que hemos obtenido para ella en Quillagua entre 660 y 665 d.C. (Agüero et al. 2001, 2006). Pero que, coincidente con las fechas de radiocarbono de Tarapacá 40 pudo haberse iniciado un poco antes, igual como lo sugieren otras dataciones por termoluminiscencia de 200 y 290 d.C. para cerámica semejante en Quillagua y recientemente en Pisagua (Gallardo et al. 1991; Méndez-Quirós y Uribe 2010). Asimismo, pudo continuar en uso hasta más tarde según un fechado de 970 d.C. en Caserones 1 y por muestras superficiales de Quillagua que colindan con los inicios del Intermedio Tardío (Agüero et al. 2001; MéndezQuirós y Uribe 2010). Complementariamente, el tipo QRP cuenta con una fecha por termoluminiscencia de 895 d.C. en Caserones (Méndez-Quirós y Uribe 2010), confirmando que se trata de expresiones cerámicas contemporáneas y que ambas representan la alfarería del Formativo Tardío. En definitiva, al igual que en Arica pero sin ser la misma cerámica Faldas del Morro a diferencia de lo que opinaba Núñez (1969) ${ }^{6}$, la alfarería Quillagua Tarapacá estaría ligada a lo cotidiano y ceremonial que por lo sencillo o tosco de su producción y heterogeneidad petrográfica es evidente que no necesitó ser conseguida por intercambio, sino que bien pudo ser elaborada localmente, coincidente con lo planteado por Kautz y colaboradores (1980).

De este modo, se confirma que la tecnología cerámica exhibe un elaborado conocimiento entre las antiguas poblaciones de Tarapacá como parece ocurrir en el resto de los Valles Occidentales, aunque todavía falta por dilucidar este hecho con contextos más domésticos y también tempranos, para lo cual contamos con muy pocas muestras por el momento, salvo por las muy sugerentes de Cáñamo y Punta Pichalo en la costa (Bird 1943; Núñez y Moragas 1983; Rivera 1988-89). Justamente, en este trabajo nos interesa abordar estas falencias no sólo completando la caracterización de la alfarería formativa temprana, sino además analizando las secuencias y su comportamiento en sitios paradigmáticos de la región.

\section{Comportamiento de los Sitios de la Pampa del Tamarugal y Consideraciones Cronológicas}

Conforme con estos antecedentes, análisis de laboratorio y trabajos de campo, nos abocamos a evaluar la tipología expuesta a partir de la cerámica superficial y excavaciones de cuatro asentamientos ubicados en las quebradas de Tarapacá y Guatacondo. Se trabajaron los sitios Pircas y Caserones 1 por una parte, y Guatacondo 1 y Ramaditas por la otra, que representan respectivamente los sectores septentrional y meridional de esta pampa (Figuras 11, 12 y 13). El material se recuperó mediante un muestreo dirigido de acuerdo a la diversidad arquitectónica de los asentamientos (Tabla 1), dando por resultado 1.526 fragmentos tanto de superficie $(\mathrm{n}=1.136)$ como de excavación $(n=390)$. Pircas reúne la mayor cantidad de materiales, correspondiente al 76,82\% de la muestra, proveniente de $47(8,36 \%)$ recintos únicos o de pequeños conglomerados dispersos de un total de 562 estructuras registradas en casi 90 ha. A lo anterior se suma, aunque muy por debajo, el material de Guatacondo que comprende un $12,12 \%$, obtenido de $16(9,03 \%)$ recintos que forman un asentamiento de 177 estructuras 


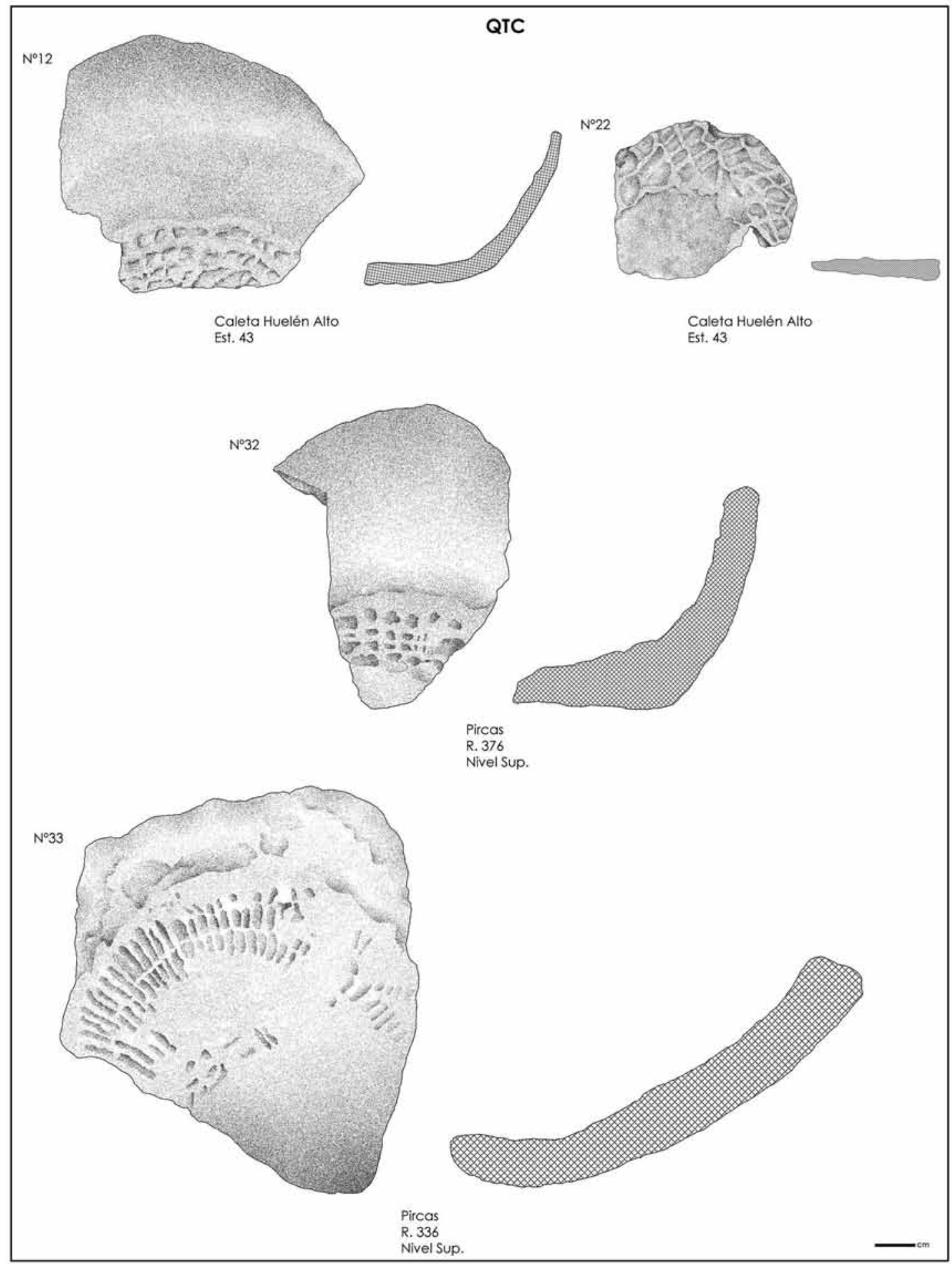

Figura 8. Fragmentos de bases con improntas de cestería del tipo Quillagua Tarapacá Café Amarillento (QTC) (dibujo de P. Chávez). Base fragments with basketry imprints of the Quillagua Tarapacá Café Amarillento (QTC) type (drawn by P. Chávez). 


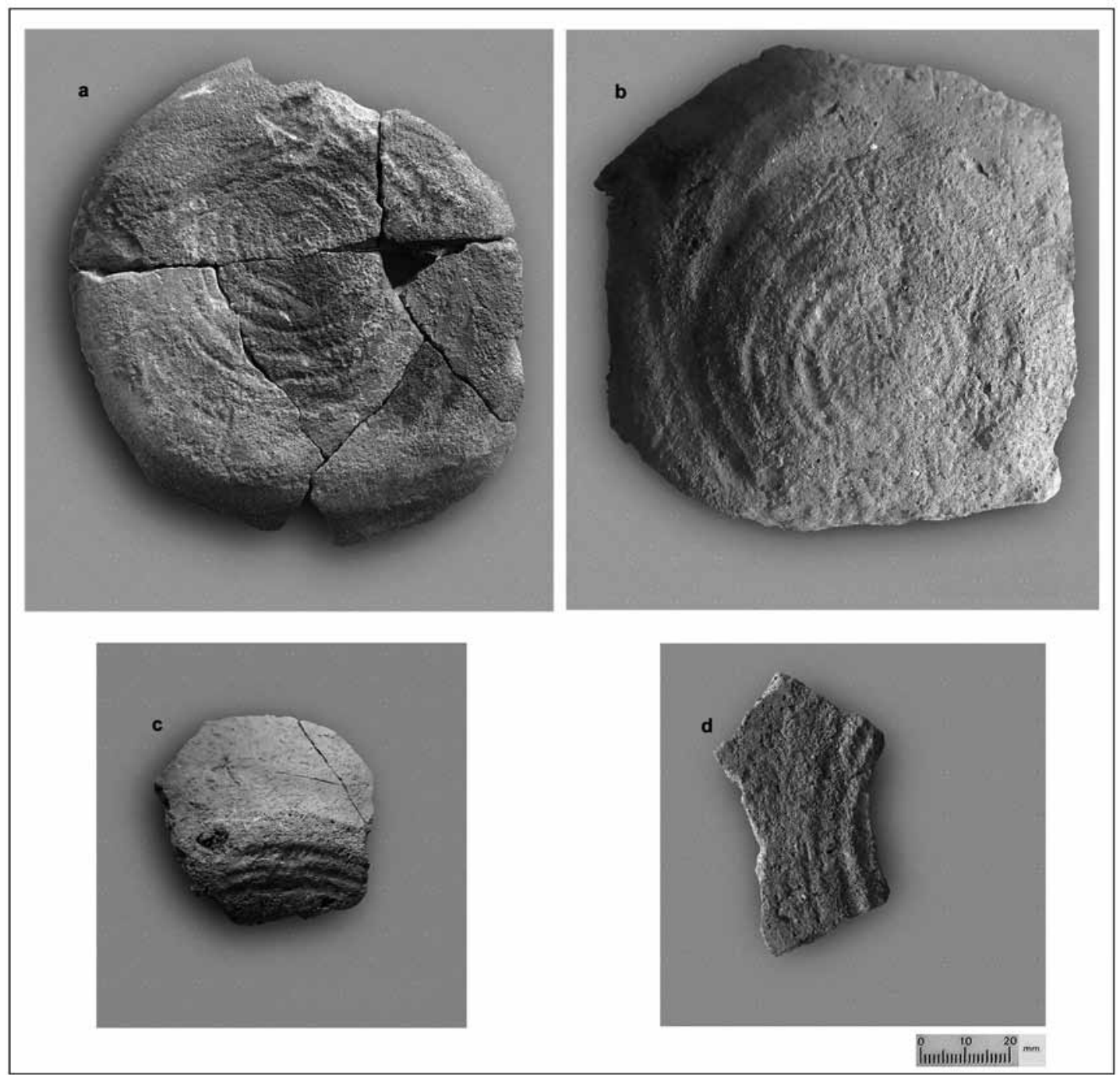

Figura 9. Ejemplos de bases con improntas de cestería del tipo Quillagua Tarapacá Café Amarillento (QTC) (a-d). Example of base fragments with basketry imprints of the Quillagua Tarapacá Café Amarillento (QTC) type (a-d).

aglutinadas. Finalmente, se encuentran Caserones y Ramaditas que sólo abarcan $9,57 \%$ y 2,49\% de los fragmentos en cada caso. Respecto al primero de ellos el material deriva de cuatro recintos de un total de 645, pero que en esta oportunidad fueron intervenidos con el propósito de completar nuestros anteriores análisis que abarcaron hasta el 10\% del sitio (Uribe et al. 2007). En cuanto a Ramaditas, la cerámica proviene de cuatro $(4,81 \%)$ recintos de un total de 83 estructuras dispersas y un sector de posible uso agrícola directamente asociado (Campo 1), los cuales también fueron recolectados para complementar el análisis de Guatacondo. En consecuencia, centramos el estudio en las muestras obtenidas para Pircas y Guatacondo, mientras que las de Caserones y Ramaditas las incluimos con fines comparativos y para la discusión final.

En la muestra analizada se determinó la presencia de 10 clases cerámicas, todas ellas correspondientes a tipos cerámicos seguros y algunos dudosos, junto con dos categorías residuales referidas a Arcilla (ARC) y Erosionados (ERO). En primer lugar, se registró la presencia del tipo Loa Café Alisado (LCA) junto con la posible existencia del tipo Los Morros (LMS? [Uribe 2006]); a ellos se unen los tipos Quillagua Tarapacá Café Amarillento (QTC), Quillagua Rojo Pulido (QRP), Caserones Negro Pulido (CNP) y San Pedro Negro Pulido en su variedad Sequitor 


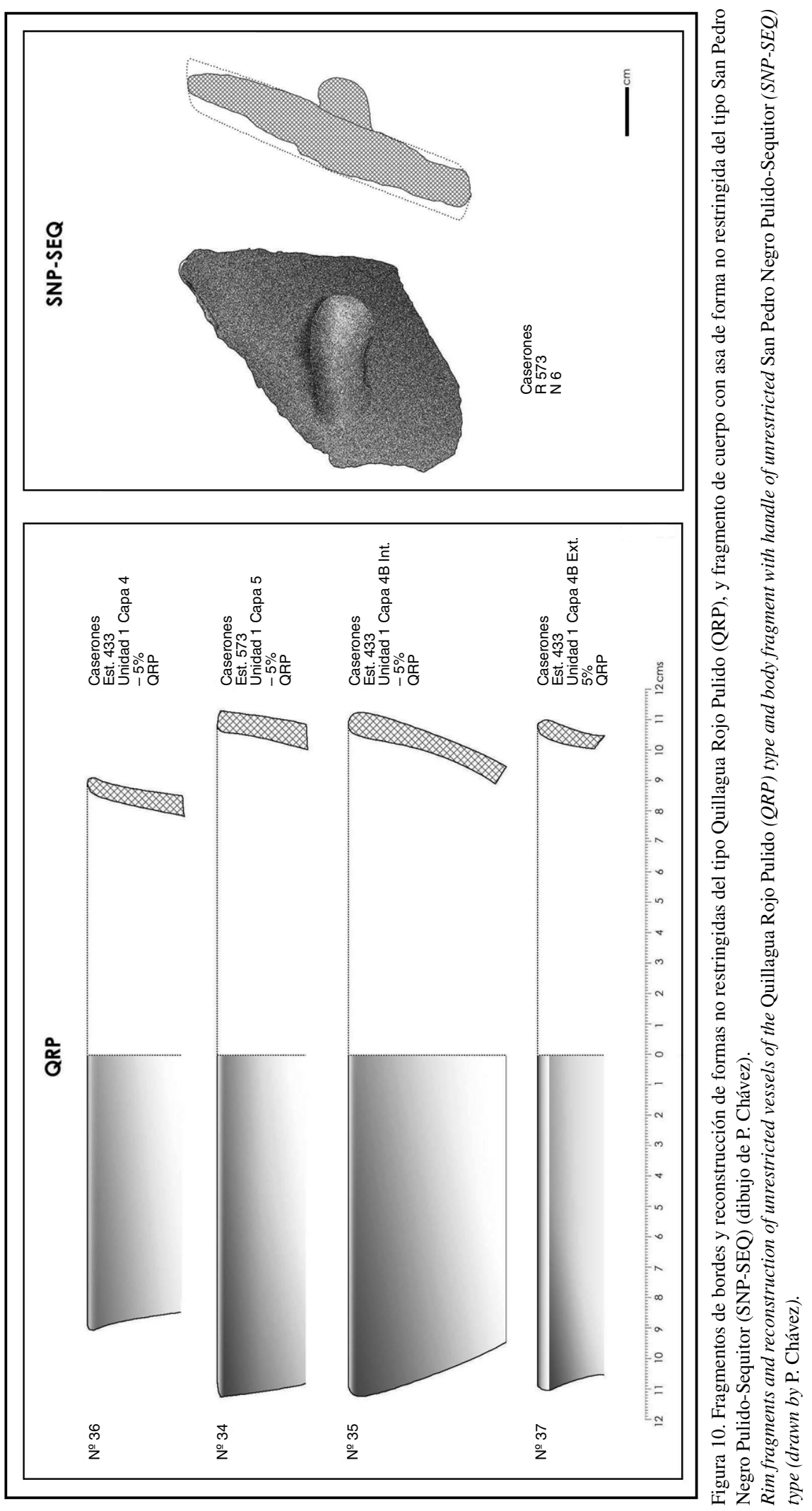




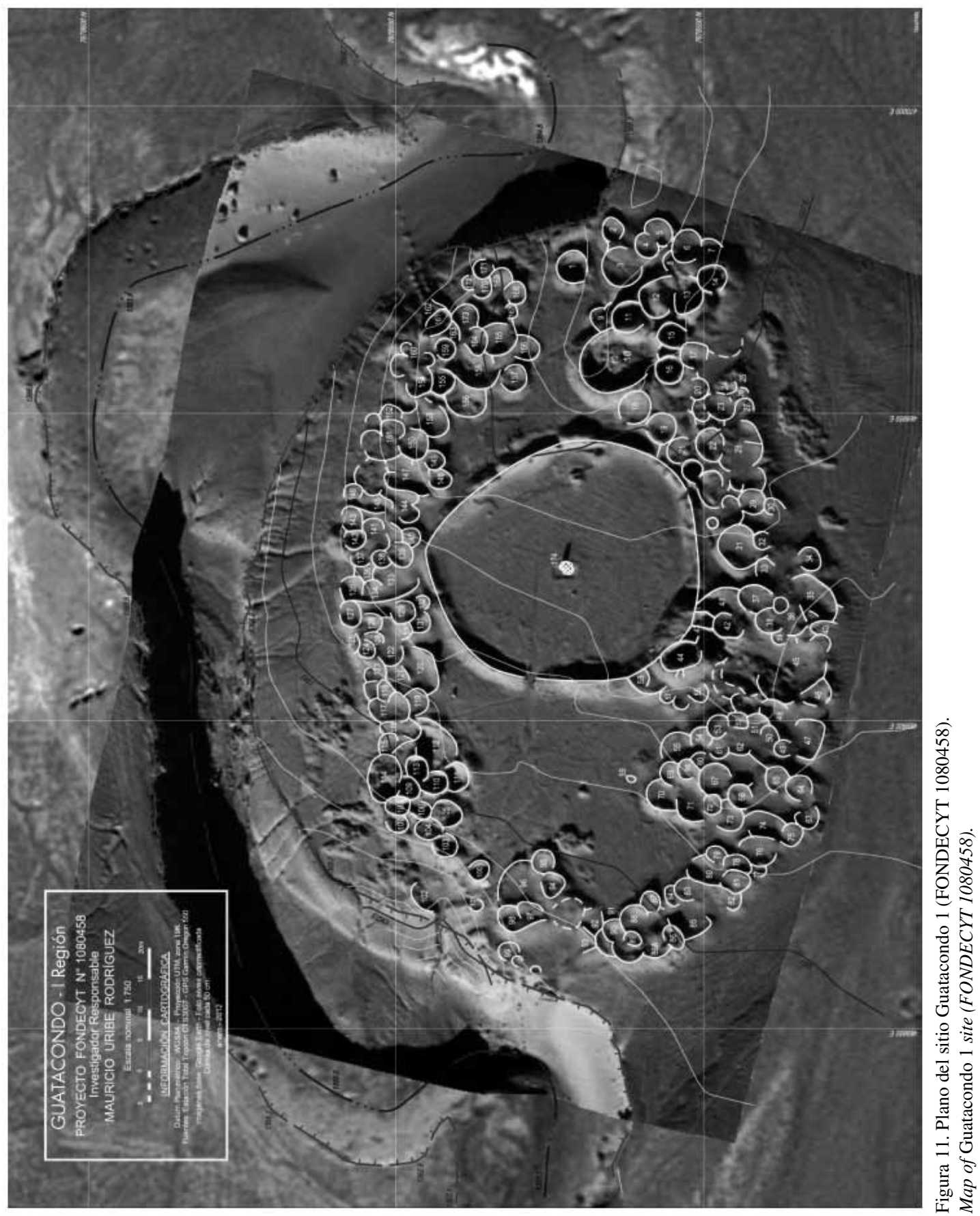



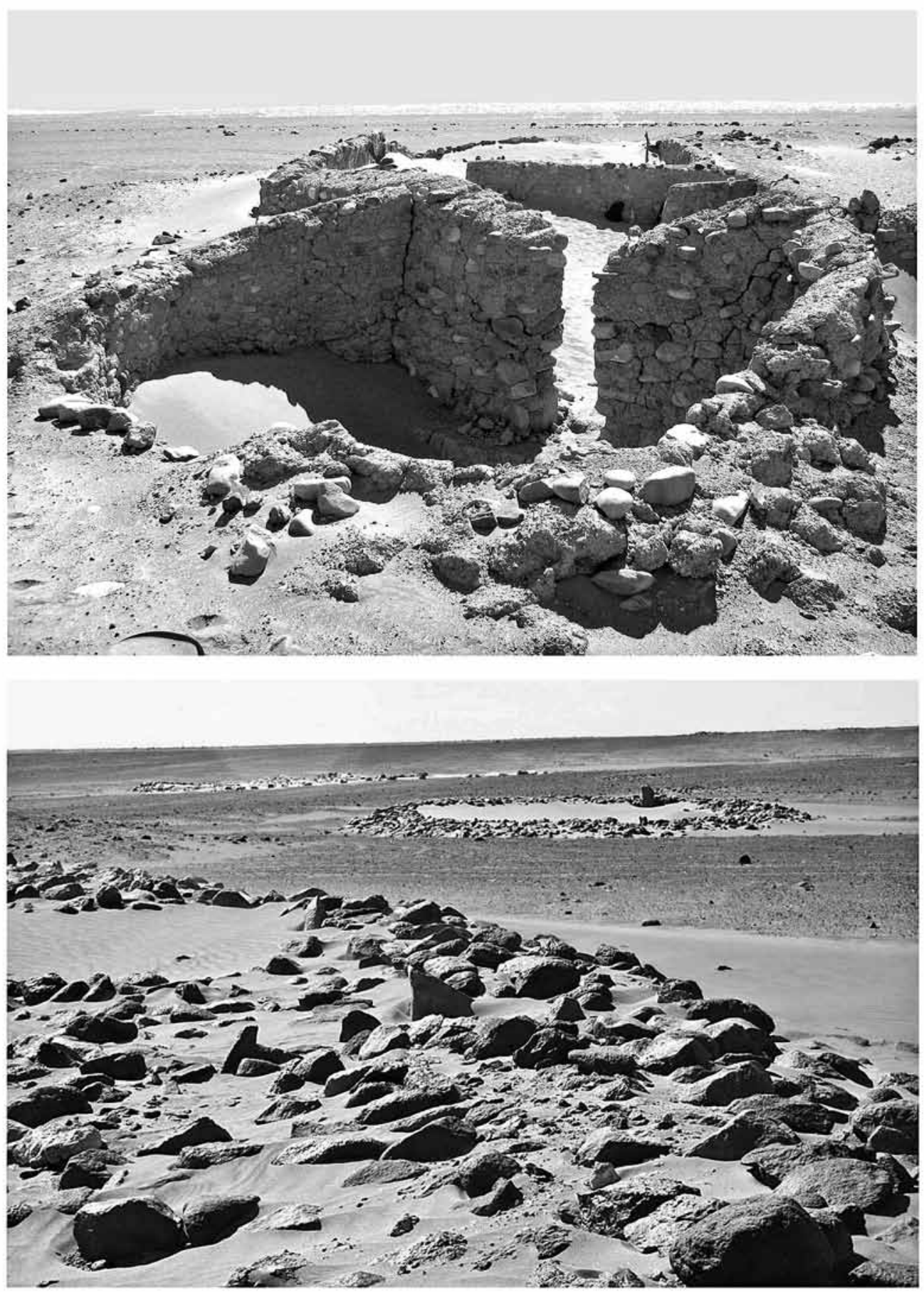

Figura 12. Estructuras arquitectónicas de los sitios Ramaditas y Pircas (FONDECYT 1080458).

Architectural structures from the sites of Ramaditas and Pircas (FONDECYT 1080458). 
Tabla 1. Proveniencia de las muestras cerámicas según sitios, estructura o recinto y origen estratigráfico (superficie y/o excavación). Provenience of ceramic samples by site, structure or room, and stratigraphic origins (surface and/or excavation).

\begin{tabular}{|c|c|c|c|c|c|c|c|c|c|}
\hline \multicolumn{3}{|c|}{ Pircas } & \multicolumn{3}{|c|}{ Guatacondo 1} & \multicolumn{2}{|c|}{ Ramaditas } & \multicolumn{2}{|c|}{ Caserones 1} \\
\hline Estructura & Rec. Sup. & Excavación & Estructura & Rec. Sup. & Excavación & Estructura & Rec. Sup. & Estructura & Excavación \\
\hline 4 & 39 & & 3 & 3 & 31 & 9 & 5 & 61 & 43 \\
\hline 11 & 27 & 13 & 27 & 3 & & 10 & 15 & 234 & 48 \\
\hline 13 & 2 & & 35 & 2 & & 41 & 1 & 433 & 33 \\
\hline 18 & 1 & & 51 & 3 & & 73 & 4 & 573 & 22 \\
\hline 38 & 43 & & 64 & 1 & 1 & Campo 1 & 13 & Subtotal & 146 \\
\hline 43 & 4 & & 69 & 2 & & Subtotal & 38 & & \\
\hline 54 & 1 & & 85 & 3 & & & & & \\
\hline 63 & 0 & 1 & 93 & 5 & & & & & \\
\hline 66 & 13 & & 94 & 1 & & & & & \\
\hline 89 & 40 & & 99 & 7 & 3 & & & & \\
\hline 107 & 8 & 6 & 106 & 1 & 1 & & & & \\
\hline 113 & 28 & & 132 & 2 & & & & & \\
\hline $113 \mathrm{~A}$ & 3 & & 153 & 1 & 4 & & & & \\
\hline 116 & 2 & 2 & 164 & 1 & 9 & & & & \\
\hline 126 & 24 & & 172 & 2 & & & & & \\
\hline 145 & 265 & & 174 & 99 & & & & & \\
\hline 166 & 3 & & Subtotal & 136 & 49 & & & & \\
\hline 183 & 55 & & & & & & & & \\
\hline 184 & 50 & & & & & & & & \\
\hline 188 & 8 & & & & & & & & \\
\hline 198 & 15 & 15 & & & & & & & \\
\hline 207 & 3 & & & & & & & & \\
\hline 214 & 44 & & & & & & & & \\
\hline 218 & 7 & & & & & & & & \\
\hline 232 & 12 & 15 & & & & & & & \\
\hline 238 & 2 & 11 & & & & & & & \\
\hline 251 & 5 & 3 & & & & & & & \\
\hline 263 & 1 & & & & & & & & \\
\hline 268 & 0 & 1 & & & & & & & \\
\hline 269 & 17 & 19 & & & & & & & \\
\hline 277 & 9 & & & & & & & & \\
\hline 288 & 12 & 12 & & & & & & & \\
\hline 336 & 5 & & & & & & & & \\
\hline 345 & 37 & 46 & & & & & & & \\
\hline 361 & 14 & & & & & & & & \\
\hline 362 & 29 & & & & & & & & \\
\hline 376 & 10 & 5 & & & & & & & \\
\hline 378 & 1 & & & & & & & & \\
\hline 385 & 16 & 1 & & & & & & & \\
\hline 388 & 1 & & & & & & & & \\
\hline 400 & 8 & & & & & & & & \\
\hline 405 & 5 & & & & & & & & \\
\hline 434 & 7 & & & & & & & & \\
\hline 463 & 13 & 16 & & & & & & & \\
\hline 472 & 50 & 26 & & & & & & & \\
\hline 489 & 2 & 3 & & & & & & & \\
\hline 498 & 21 & & & & & & & & \\
\hline Subtotal & 962 & 195 & & & & & & Total & 1.526 \\
\hline
\end{tabular}




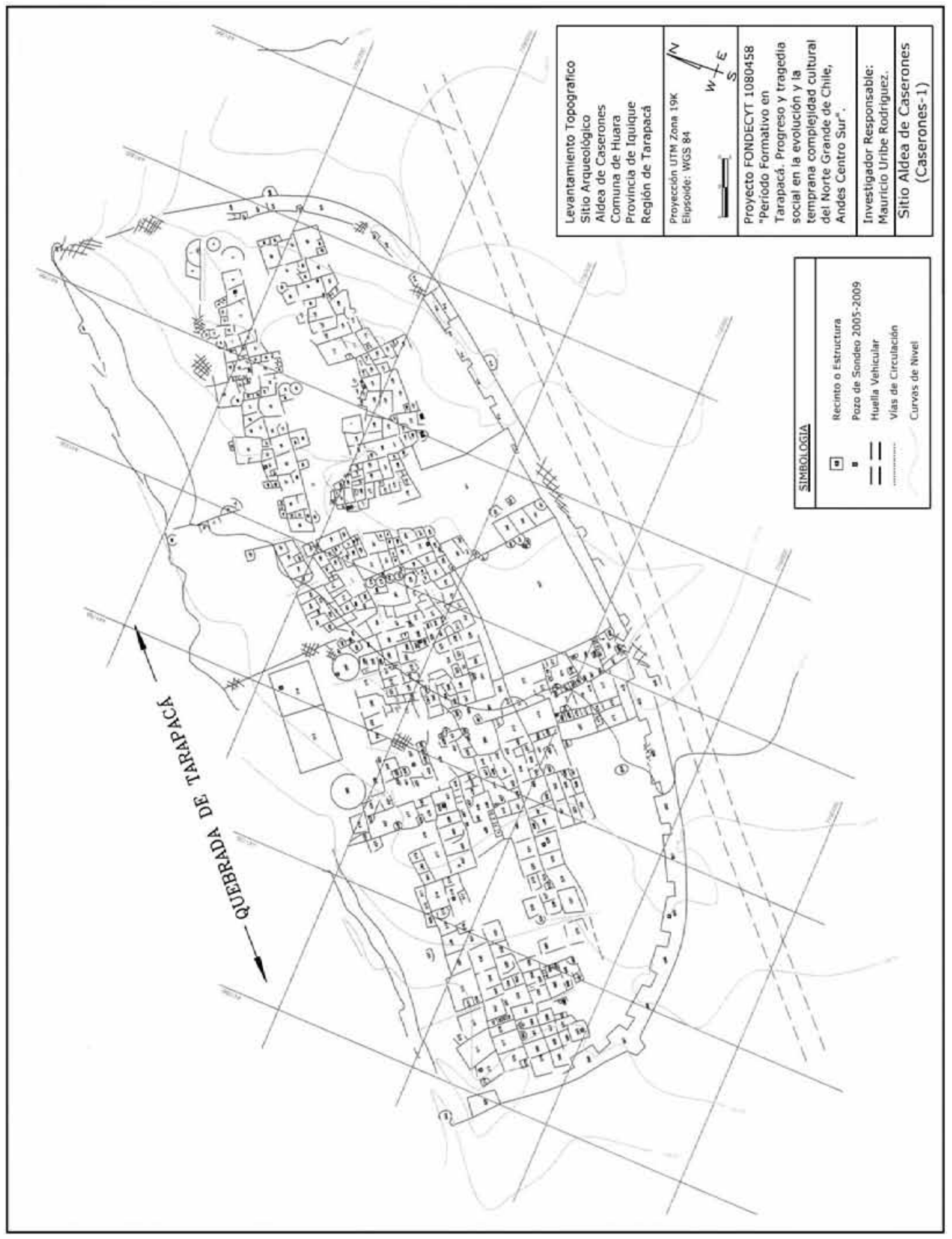

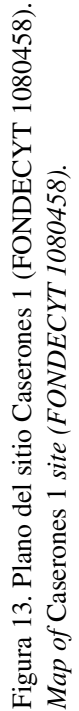


(SNP-SEQ). Estos los agrupamos dentro de un componente temprano que se remontaría al período Formativo (900 a.C.-900 d.C.), distinguiéndose un conjunto acotado al Formativo Temprano (900 a.C.200 d.C.), compuesto por los tipos LCA y LMS?; mientras que un segundo conjunto constituido por los tipos QTC, QRP, CNP y SNP, sería propio del Formativo Tardío (200 d.C.-900 d.C.). A partir de los antecedentes expuestos, la mayor parte de esta alfarería tendría una marcada vinculación con el territorio tarapaqueño, a la vez que se relacionaría con algunas expresiones del Loa, específicamente en el caso de los tipos LMS y SNP (Uribe 2006; Uribe y Ayala 2004).

También aparecen evidencias bastante menores tanto de la costa como del interior que refieren a los componentes Pica-Tarapacá, Altiplano e Incaico (Pica Charcollo [PCH], Pica Gris Alisado [PGA], posiblemente Chilpe Negro sobre Rojo [CHP?] e Inca Altiplánico [IKL?]), constituidos por tipos no decorados y decorados pertenecientes a los períodos Intermedio Tardío y Tardío de Tarapacá (900-1.550 d.C.). Lo anterior sugiere un leve contacto con momentos iniciales y terminales de la prehistoria tardía de la región, con seguridad correspondientes a las fases Tarapacá (900-1.200 d.C.) y Camiña (1.200-1.450 d.C.) adscritas al complejo Pica Tarapacá (Uribe et al. 2007).

En definitiva, el material se reparte principalmente entre los componentes cerámicos Formativo y Pica Tarapacá, aunque el primero de ellos es absolutamente predominante, ya que representa alrededor del $75 \%$ de la muestra, seguido mucho después por el segundo con poco más del $10 \%$ (Figura 14). Según se desprende de los análisis previos que hicimos para Caserones (Uribe et al. 2007), la secuencia tipológica formativa transitaría hacia el Intermedio Tardío pero mostrando una menor frecuencia, al menos en la parte inferior de la quebrada y la Pampa del Tamarugal (Uribe 2010). Conforme con este panorama, ahora nos interesa detallar la caracterización cronológica de la cerámica del Formativo de Tarapacá (Uribe 2009a; Uribe et al. 2007). Y, en particular, completar y ahondar en la secuencia abordando un todavía escurridizo Formativo Temprano y de esta manera avanzar en la comprensión de la complejidad social hacia el Formativo Tardío. Con estos propósitos, nos centramos en el análisis de las muestras cerámicas de superficie y excavación provenientes de los sitios mencionados.

\section{Recolecciones de Superficie en Pircas, Guatacondo y Ramaditas}

En cuanto al material de superficie de Pircas ( $\mathrm{n}=962)$, éste se presenta más bien escaso. En primer lugar, porque no se detectó en la totalidad del 10\% $(n=45)$ de las estructuras recolectadas (56 de 562); y luego, porque el número de fragmentos encontrados no varía más allá de uno a 55 trozos en el $97,77 \%$ de los recintos muestreados.

La mayor frecuencia la concentra el tipo LCA, seguido por el QTC y luego por el tipo $\mathrm{PCH}$, mientras que en proporciones muy menores se encuentran los tipos CNP, CHP? e IKL (cerca de $1 \%$ respectivamente). Por lo tanto, casi el $86 \%$ de la muestra representa ocupaciones del Formativo (Figura 15), destacando la cerámica del Formativo Temprano con un $61,3 \%$ (tipo LCA); mientras que el $12,78 \%$ correspondería al Formativo Tardío (tipos QTC y CNP). En tanto, 10,84\% referiría a los períodos Intermedio Tardío $(10,7 \%)$ y Tardío, mientras que $14,03 \%$ de la cerámica se encuentra erosionada. Dentro de una ocupación bicomponente, es posible afirmar que la principal actividad estuvo enmarcada en momentos iniciales y tardíos del Formativo tarapaqueño y del Loa, lo que sugeriría un lapso de ocupación que abarcaría entre 900 a.C. y 200 d.C. por una parte, y desde 200 a 900 d.C. por otra.

En el caso de Guatacondo también podemos señalar que el material cerámico se presenta más bien escaso $(n=136)$, pues tampoco se detectó en la totalidad del $10 \%(n=16)$ de las estructuras seleccionadas (18 de 177), y porque el número de fragmentos encontrados no varía más allá de uno a siete trozos en el $93,75 \%$ de los recintos muestreados. La mayor frecuencia también la concentra el tipo LCA (97\%), esta vez acompañado exclusivamente aunque en proporciones muy menores por el tipo LMS? del Formativo Temprano atacameño. En consecuencia, casi el $100 \%$ de la muestra representaría ocupaciones del período Formativo Temprano, puesto que la cerámica erosionada apenas alcanza un 1\% (Figura 16). Esto da cuenta de una ocupación monocomponente bajo predominio tarapaqueño pero también relacionado con el Loa, y en la práctica nulos vínculos con las etapas más tardías de la región. Así, es posible afirmar que la ocupación estuvo enmarcada en momentos iniciales del Formativo dentro de un lapso que abarcaría desde 900 a.C. a 200 d.C. 


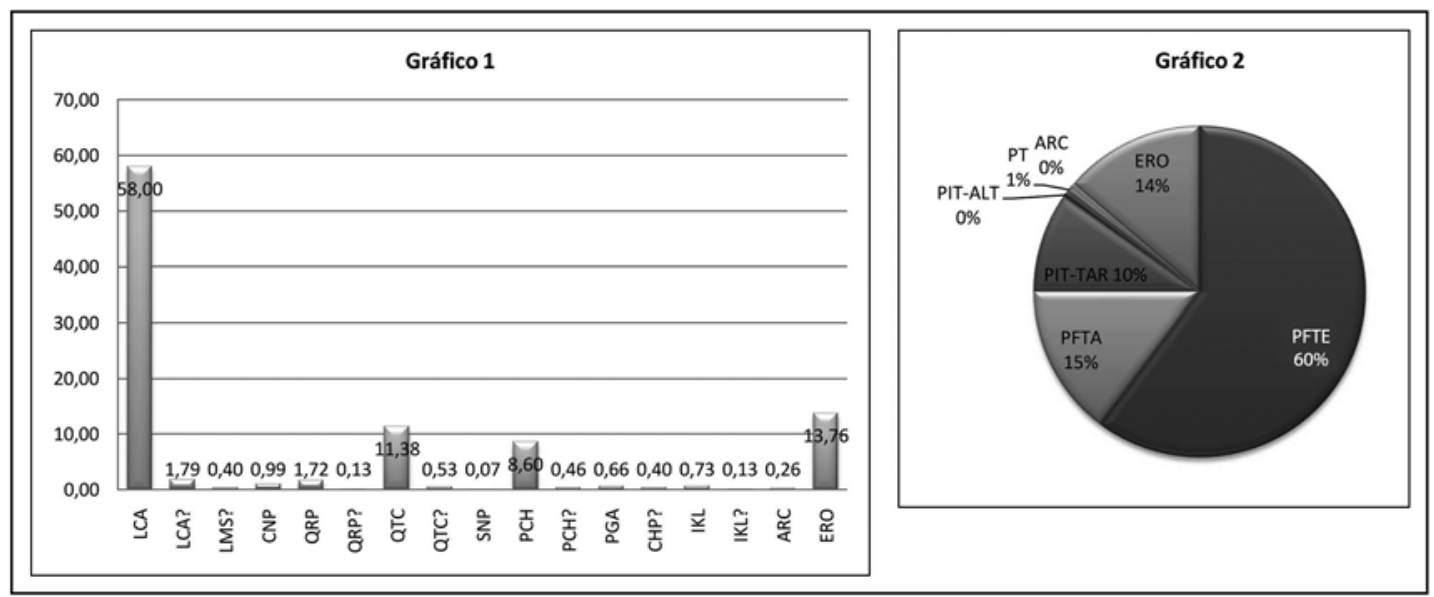

Figura 14. Gráficos 1 y 2: Tipos cerámicos y frecuencias relativas de la muestra general (1). Componentes cerámicos y frecuencias relativas de la muestra general (2).

Graphics 1 and 2: Ceramic types and relative frequencies of the total sample (1). Ceramic components and relative frequencies of the total sample (2).

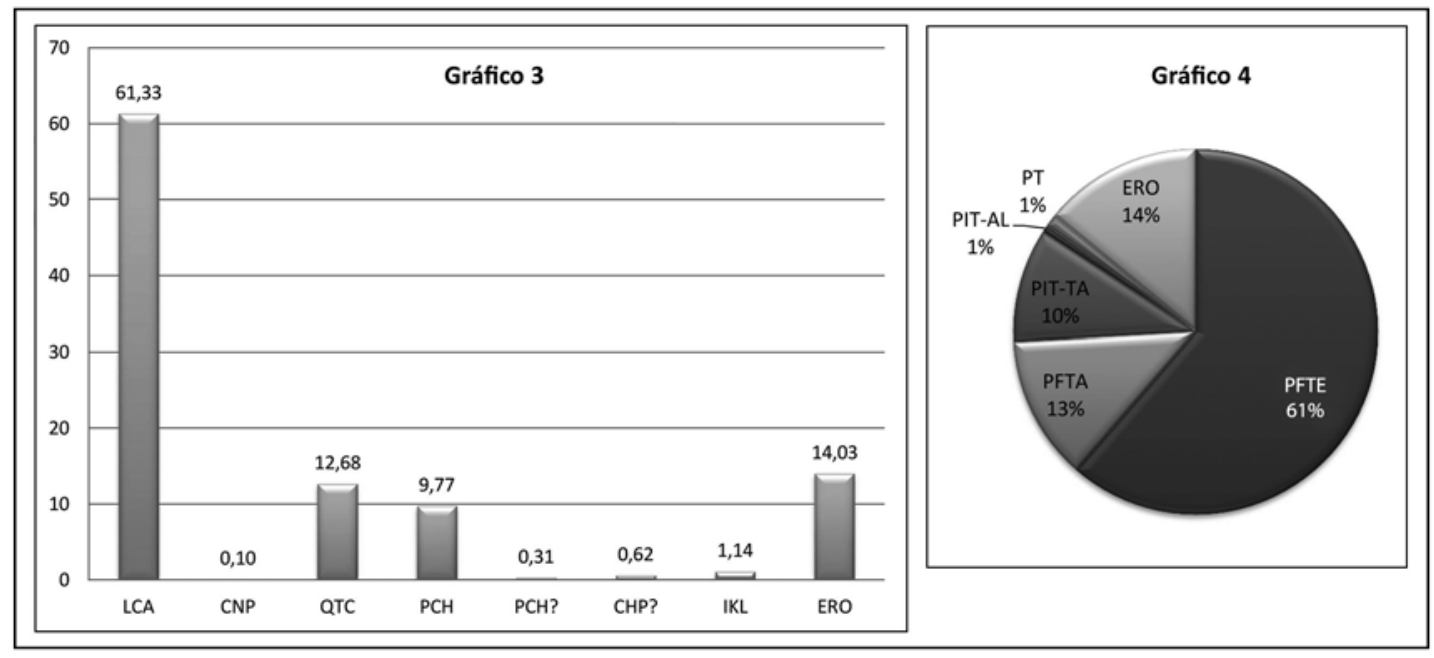

Figura 15. Gráficos 3 y 4: Tipos cerámicos y frecuencias relativas de la muestra de superficie de Pircas (3). Componentes cerámicos y frecuencias relativas de la muestra de superficie de Pircas (4).

Graphics 3 and 4: Ceramic types and relative frequencies of the Pircas surface sample (3). Ceramic components and relative frequencies of the Pircas surface samples (4).

Con el propósito de contar con información comparativa para Guatacondo, debido a su menor envergadura respecto a Pircas, incluimos al sitio Ramaditas. En este caso también seleccionamos el $10 \%$ de las estructuras $(n=8)$, pero apenas se recolectó cerámica en cuatro de ellas y el campo asociado y en cantidades que en un solo caso alcanzaron los 15 fragmentos de un total de 38 . En este caso, prácticamente también el 100\% del material corresponde al tipo LCA y, por lo tanto, el componente del Formativo es igualmente dominante
(Figura 17), demostrando que ambos asentamientos se desarrollarían acotados a sus momentos iniciales y sin una prolongación significativa hacia el Formativo Tardío ni al Intermedio Tardío como en Pircas.

\section{Excavaciones en Guatacondo, Pircas y Caserones}

A partir de lo realizado, entonces, se propone una sólida secuencia cerámica y ocupacional para el período Formativo de los oasis y valles interiores 


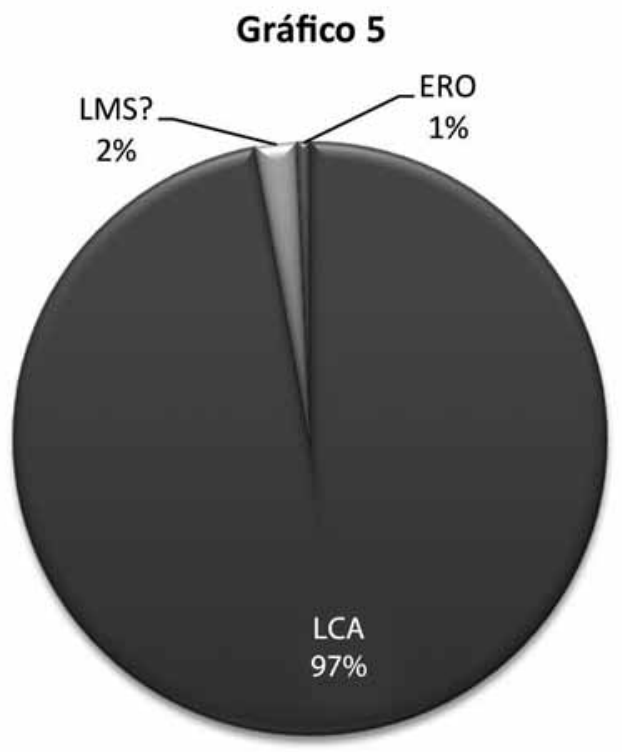

Figura 16. Gráfico 5: Tipos cerámicos y frecuencias absolutas de la muestra de superficie de Guatacondo.

Graphic 5. Ceramic types and absolute frequencies of the Guatacondo surface sample.

de Tarapacá (Tabla 2). Por un lado, los sitios de Guatacondo y Ramaditas resultan ser una expresión bastante pura del Formativo Temprano, mientras que en el otro extremo se encontraría Caserones con manifestaciones propias del Formativo Tardío que se extenderían hasta comienzos del Intermedio Tardío (Uribe et al. 2007). Por último, como una situación intermedia aparece Pircas, el cual exhibe los dos momentos del componente. Para fundamentar estratigráficamente estas apreciaciones, a continuación revisamos los materiales provenientes de las excavaciones en estos asentamientos.

\section{Guatacondo}

En este caso se excavaron cuadrículas de $1 \mathrm{~m}^{2}$ al interior de siete recintos, donde se distinguieron hasta siete estratos y algunos rasgos, pero donde se obtuvieron tan sólo 49 fragmentos de cerámica en seis de las unidades (unos siete trozos como promedio por cuadrícula). Por lo tanto, el sitio presenta escasa cantidad de material, donde el $12,24 \%$ proviene de los niveles superficiales, $81,63 \%$ se concentra en los niveles intermedios y $6,12 \%$ pertenece a los niveles inferiores (Tabla 3). Un $74 \%$ de la cerámica corresponde a tipos formativos

\section{Gráfico 6}

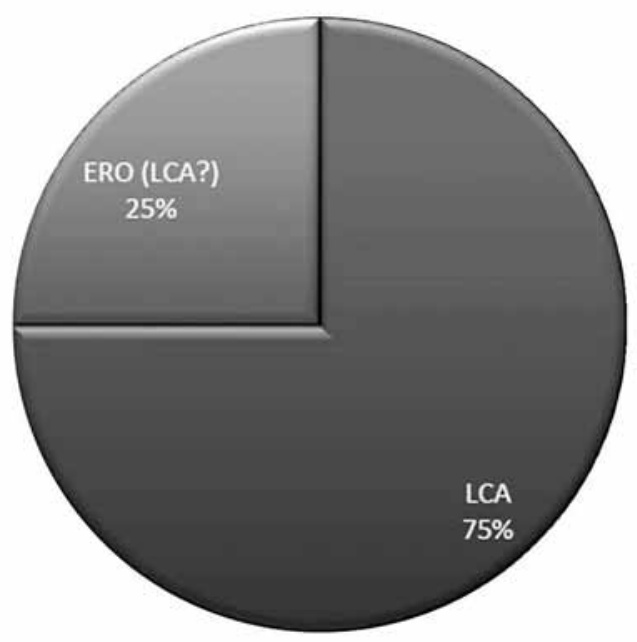

Figura 17. Gráfico 6: Tipos cerámicos y frecuencias absolutas de la muestra de superficie de Ramaditas.

Graphic 6. Ceramic types and absolute frequencies of the Ramaditas surface sample.

(Figura 18), sobre todo de Tarapacá pero también del Loa (tipos LCA y LMS? respectivamente). El tipo LCA es el más frecuente $(67,35 \%)$, pues aparece en todos los recintos y en la mayoría de los estratos (seis de siete); le acompaña muy por debajo el tipo LMS?, seguido por una expresión tarapaqueña dudosamente más tardía o terminal del Formativo (tipo PGA) en iguales proporciones $(6,12 \%)$. Los fragmentos erosionados alcanzan $14 \%$ y $6 \%$ los restos de arcilla. Lo anterior confirma lo inferido a partir del material de superficie por cuanto la cerámica de excavación también inscribe a Guatacondo dentro de un Formativo Temprano sin mayores intervenciones posteriores, reafirmado por la presencia de posible alfarería atacameña de aquella misma época (Uribe 2006). Esto sería consistente con los fechados calibrados y no calibrados conocidos hasta el momento, ubicando su ocupación inicial hacia 880 a.C. (Tartaglia 1980; Tabla 2). Complementariamente, aunque en Ramaditas no detectamos ningún fragmento cerámico en las excavaciones de siete recintos, una considerable cantidad de fechas obtenidas aquí apoyan nuestra inferencia cronológica, puesto que en su totalidad éstas son anteriores a nuestra era, comenzando en 806-755 cal. a.C. (Rivera 2005; Rivera et al. 
Tabla 2. Fechados radiocarbónicos de los sitios analizados (Proyecto FONDECYT 1080458).

Radiocarbon dates of the sites included in this analysis (Project FONDECYT 1080458).

\begin{tabular}{|c|c|c|c|c|c|}
\hline Código & Sitio & Recinto & Nivel & Muestra & $\begin{array}{l}\text { Rango de edad calendárica } \\
\qquad(P=0,95)\end{array}$ \\
\hline Beta-314509 & Ramaditas & 17 & Superficie & Madera & $\begin{array}{l}390-340 \text { cal. a.C. } \\
320-200 \text { cal. a.C. }\end{array}$ \\
\hline Beta-314510 & Ramaditas & 41 & 4 & Madera & $\begin{array}{l}\text { 390-340 cal. a.C. } \\
\text { 320-200 cal. a.C. }\end{array}$ \\
\hline Beta-314512 & Ramaditas & 9 & 3/Rasgo 1 & Carbón & $\begin{array}{c}\text { 350-320 cal. a.C. } \\
\text { 210-90 cal. a.C. } \\
\text { 80-50 cal. a.C. }\end{array}$ \\
\hline Beta-314511 & Ramaditas & 41 & 1 & Carbón & $\begin{array}{l}110 \text { cal. a.C.-30 cal. d.C. } \\
40-50 \text { cal. d.C. }\end{array}$ \\
\hline Beta-314508 & Ramaditas & 51 exterior & 1/Rasgo 1 & Carbón & 40 cal. a.C. -80 cal. d.C. \\
\hline Beta-294697 & Guatacondo & 153 & 7 & Carbón & $\begin{array}{c}340-330 \text { cal. a.C. } \\
200 \text { cal. a.C. }-20 \text { cal. d.C. }\end{array}$ \\
\hline Beta-294696 & Guatacondo & 99 & Rasgo 1 & Carbón & 200-10 cal. a.C. \\
\hline Beta-314501 & Guatacondo & 3 & 5 & Vegetal & $\begin{array}{l}160-130 \text { cal. a.C. } \\
120 \text { cal. a.C. }-10 \text { cal. d.C. } \\
10-20 \text { cal. d.C. }\end{array}$ \\
\hline Beta-294698 & Guatacondo & 164 & 4 & Carbón & 160 cal. a.C. -60 cal. d.C. \\
\hline Beta-314500 & Guatacondo & 153 & 7 & Vegetal & $\begin{array}{c}\text { 90-80 cal. a.C. } \\
50 \text { cal. a.C. }-60 \text { cal. d.C. }\end{array}$ \\
\hline Beta-314502 & Guatacondo & 3 & 4 & Carbón & 50 cal. a.C. -70 cal. d.C. \\
\hline Beta-294700 & Pircas & 232 & 3 & Carbón & $\begin{array}{l}370-150 \text { cal. a.C. } \\
140-110 \text { cal. a.C. }\end{array}$ \\
\hline Beta-294701 & Pircas & 251 & 3B & Carbón & 80-230 cal. d.C. \\
\hline Beta-294699 & Pircas & 198 & Rasgo 2 & Madera & $\begin{array}{l}350-440 \text { cal. d.C. } \\
490-520 \text { cal. d.C. }\end{array}$ \\
\hline Beta-294702 & Pircas & 269 & 3B & Madera & $\begin{array}{l}380-450 \text { cal. d.C. } \\
450-460 \text { cal. d.C. } \\
480-530 \text { cal. d.C. }\end{array}$ \\
\hline Beta-294695 & Caserones & 61 & 7 & Carbón & 20-240 cal. d.C. \\
\hline Beta-220919 & Caserones & 526 & $5 \mathrm{C}$ & Carbón & 80-250 cal. d.C. \\
\hline Beta-220918 & Caserones & 468 & $3 \mathrm{~A}$ & Madera & 110-410 cal. d.C. \\
\hline Beta-294694 & Caserones & 433 & $2 \mathrm{~A}$ & Carbón & 250-420 cal. d.C. \\
\hline Beta-220917 & Caserones & 7 & 3 & Carbón & 890-1.020 cal. d.C. \\
\hline
\end{tabular}

Nota: Fechados calibrados a dos sigmas con el programa INTCAL 04 e INTCAL 09 (Heaton et al. 2009; Oeschger et al. 1975; Reimer et al. 2009; Stuiver y Braziunas 1993).

1995-96; Tabla 2), permitiéndonos sugerir que se trata de un mismo sistema de asentamiento al que nos referimos más adelante.

\section{Pircas}

En este caso se excavaron cuadrículas de $1 \mathrm{~m}^{2}$ al interior de 18 recintos, donde se distinguieron hasta seis estratos y algunos rasgos, pero donde se obtuvo tan sólo 195 fragmentos de cerámica en 17 de las unidades (poco más de 10 trozos como promedio por cuadrícula). Por lo tanto, el sitio también presenta escasa cantidad de material, donde el 67,02\% se concentra en los niveles superficiales, 30,89\% proviene de los niveles intermedios y 2,09\% pertenece a los niveles inferiores (Tabla 4). Un 56\% de la cerámica corresponde a tipos formativos (Figura 19), exclusivamente de Tarapacá y compartidos con el Loa inferior (tipos LCA, QTC y QRP). Otra vez el tipo LCA es el más frecuente $(49,74 \%)$, aparece en 
Tabla 3. Distribución estratigráfica de los tipos cerámicos de la muestra de Guatacondo 1 (Para éste y el resto de los casos, se ilustran sólo los tipos y las frecuencias absolutas pertenecientes a los niveles claramente estratificados, obviándose aquellos derivados de rasgos y limpieza de perfiles sin adscripción a un estrato determinado. En Gris claro: Estratos superficiales, Gris: Estratos Intermedios y Gris oscuro: Estratos inferiores).

Stratigraphic distribution of ceramic types from the Guatacondo 1 sample (For all cases, only types and absolute frequencies from clearly stratified levels are shown. Light gray: Upper strata; Gray: Middle strata; Dark gray: Lower strata).

\begin{tabular}{|c|c|c|c|c|c|c|}
\hline Capa & LCA & LMS? & PGA & $\mathrm{ARC}$ & ERO & Total general \\
\hline 1 & 4 & & & & & 4 \\
\hline 1(RASGO 1) & 2 & & & & & 2 \\
\hline 2 & 7 & & & & & 7 \\
\hline 2(RASGO 1) & 1 & & & & & 1 \\
\hline $3 \mathrm{~A}$ & 14 & 1 & 3 & & 7 & 25 \\
\hline $3 B$ & 1 & & & & & 1 \\
\hline $4(50-60 \mathrm{CM})$ & 2 & 2 & & & & 4 \\
\hline 4 & 1 & & & & & 1 \\
\hline 5 & 1 & & & & & 1 \\
\hline 7 & & & & 3 & & 3 \\
\hline Total general & 33 & 3 & 3 & 3 & 7 & 49 \\
\hline
\end{tabular}

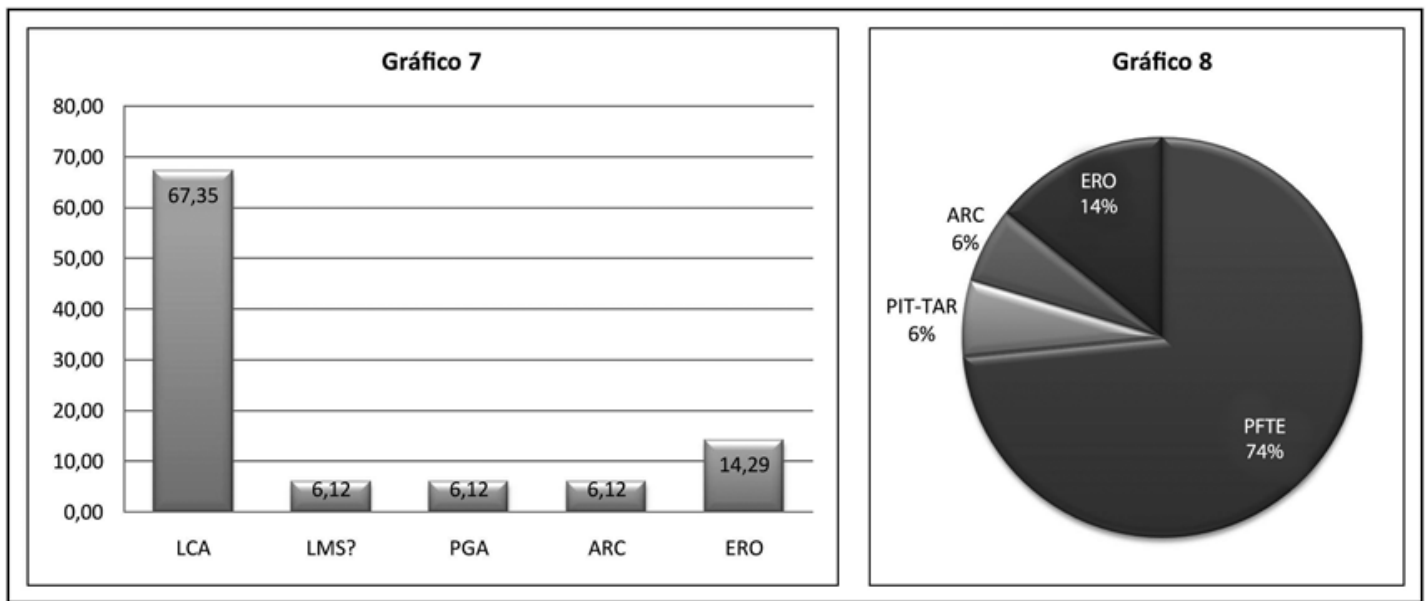

Figura 18. Gráficos 7 y 8: Tipos cerámicos y frecuencias relativas de la muestra de excavaciones de Guatacondo (7). Componentes cerámicos y frecuencias relativas de la muestra de excavaciones de Guatacondo (8).

Graphics 7 and 8: Ceramic types and relative frequencies of the Guatacondo excavation samples (7). Ceramic components and relative frequencies of the Guatacondo excavation samples (8).

casi la mayoría de los recintos (14) y en todos los estratos. Sin embargo, le acompaña luego el tipo PCH $(13,85 \%)$, seguido por el resto de las expresiones formativas del tipo QTC y QRP $(6,16 \%)$ en proporciones aún menores. Por último, se detectaron algunas posibles evidencias incaicas, en tanto los fragmentos erosionados alcanzan un $28,72 \%$, mientras que $0,51 \%$ corresponde a restos de arcilla. Esto también confirma lo inferido a partir del material de superficie, pues las excavaciones de Pircas permiten distinguir al menos dos grandes momentos, uno referido al Formativo y otro al Intermedio Tardío. A su vez, se pueden establecer otras distinciones mucho más significativas, puesto que el material propio del Formativo Temprano comprende casi el $50 \%$ de la muestra, distinguiéndose con claridad de aquel del Formativo Tardío que alcanza poco más del 6\%. Por otra parte, si además se considera la presencia única del tipo $\mathrm{PCH}$ en ausencia de otras expresiones del Intermedio Tardío (14\%), estaríamos frente a ocupaciones típicas de la quebrada de Tarapacá que se concentran entre el Formativo 
Tabla 4. Distribución estratigráfica de los tipos cerámicos de la muestra de Pircas. Stratigraphic distribution of ceramic types from the Pircas sample.

\begin{tabular}{|c|c|c|c|c|c|c|c|c|c|}
\hline Capa & LCA & QRP? & QTC & QTC? & $\mathrm{PCH}$ & IKL? & ARC & ERO & Total general \\
\hline Sup. & 6 & & 1 & & 4 & & & 22 & 33 \\
\hline 1 & 17 & 1 & 1 & 2 & 14 & 2 & & 18 & 55 \\
\hline $1 \mathrm{~A}$ & 12 & & 2 & & & & & & 14 \\
\hline $1 \mathrm{~B}$ & 1 & & 2 & & & & & 9 & 12 \\
\hline $1 \mathrm{C}$ & 6 & & & & & & & 1 & 7 \\
\hline $1 \mathrm{D}$ & 1 & & & & & & & 2 & 3 \\
\hline $1 \mathrm{E}$ & 3 & & & & & & & 1 & 4 \\
\hline 2 & 8 & 1 & 1 & & 5 & & & 3 & 18 \\
\hline $2 \mathrm{~A}$ & 6 & & & & & & & & 6 \\
\hline $2 \mathrm{~B}$ & 1 & & & & & & & & 1 \\
\hline 3 & 7 & & 1 & & 4 & & & & 12 \\
\hline Rasgo 1(3A) & 2 & & & & & & & & 2 \\
\hline $3 \mathrm{~B}$ & 14 & & & & & & & & 14 \\
\hline Rasgo 1(3B) & 1 & & & & & & & & 1 \\
\hline $4 \mathrm{~A}$ & 4 & & & & & & 1 & & 5 \\
\hline 6 & 4 & & & & & & & & 4 \\
\hline Total general & 93 & 2 & 8 & 2 & 27 & 2 & 1 & 56 & 191 \\
\hline
\end{tabular}

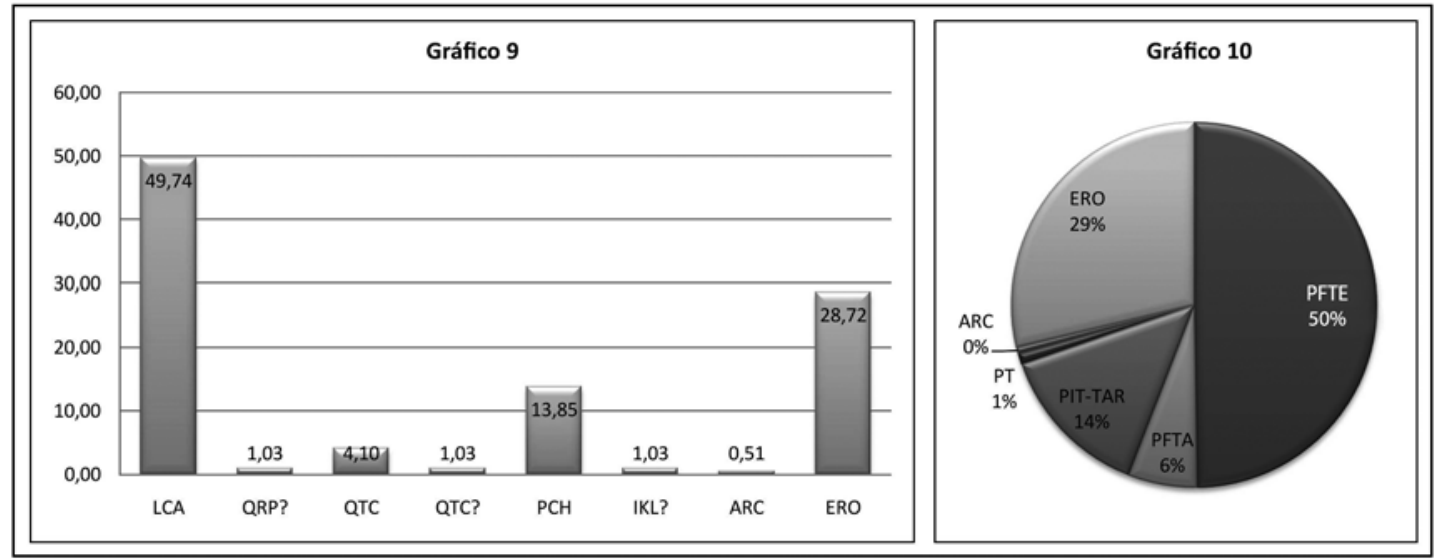

Figura 19. Gráficos 9 y 10: Tipos cerámicos y frecuencias relativas de la muestra de excavaciones de Pircas (9). Componentes cerámicos y frecuencias relativas de la muestra de excavaciones de Pircas (10).

Graphics 9 and 10: Ceramic types and relative frequencies of the Pircas excavation samples (9). Ceramic components and relative frequencies of the Pircas excavation samples (10).

Tardío e inicios del Intermedio Tardío ${ }^{7}$. Al revisar en detalle la estratigrafía, vemos que el tipo LCA es totalmente dominante, no se aprecian mayores alteraciones estratigráficas debido a la ausencia de tipos intrusivos; y las evidencias más tardías, que son bastante menores, aparecen principalmente en los niveles superiores, dando cuenta de la integridad de la secuencia. Es decir, gran parte de los tipos formativos tardíos y de inicios del Intermedio Tardío se ubican en los estratos superiores e intermedios, mientras que en los niveles intermedios más profundos e inferiores el predominio del tipo LCA es absoluto y vuelven a aparecer restos de arcilla como en Guatacondo.

En suma, la estratigrafía y la cerámica de Pircas confirman que aquí se encuentran representadas 
ocupaciones pertenecientes al Formativo Temprano (900 a.C.-200 d.C.) y secundariamente al Formativo Tardío (200-900 d.C.), las que se proyectan levemente hacia los inicios del Intermedio Tardío. Esta situación, en cierto modo, es coherente con los tres fechados no calibrados mencionados por Núñez (1984a) de 480 a.C., 70 d.C. y 500 d.C., los que junto con los nuestros (Tabla 2), permiten discriminar una época formativa previa y otra posterior a nuestra era.

\section{Caserones}

Dentro de nuestro primer estudio sobre la cerámica de Caserones (Uribe et al. 2007), se analizaron 1.830 fragmentos procedentes de la recolección de superficie de 64 recintos, así como 972 obtenidos de las excavaciones en 17 de ellos. Pudimos documentar que el sitio se distingue por presentar una importante frecuencia de tipos del Formativo Tardío (QTC y QRP=51\%), junto con los clásicos exponentes Pica Tarapacá del Intermedio Tardío (tipo $\mathrm{PCH}=48 \%$ ), constituyendo alrededor del $99 \%$ de la muestra.

De esta forma, la composición tipológica de Caserones mostró ocupaciones vinculadas con poblaciones tarapaqueñas que, sin claras manifestaciones del Formativo Temprano, se extendería desde el Formativo Tardío hasta el período Intermedio Tardío en su porción inicial, en ausencia de los componentes Altiplánico, Incaico e Histórico. Por otra parte, la distribución superficial de los tipos cerámicos de ambos períodos resultó muy homogénea, dominando claramente lo local y una escasa variedad tipológica donde ambos componentes aparecen juntos casi en la totalidad de los recintos recolectados. De hecho, la presencia de materiales foráneos fue mínima, evidenciando escasos nexos cerámicos con las regiones circundantes que se remiten casi exclusivamente al Loa y Atacama. De acuerdo con esto, se asumió la existencia de al menos dos ocupaciones para Caserones dentro de una continuidad cultural que tendría como base el período Formativo Tardío, cerca de 200 d.C., y que luego se desarrollaría hacia inicios del Intermedio Tardío alrededor de 900 d.C. Las excavaciones apoyaron estas apreciaciones, ya que si bien se mantienen juntos, en estratigrafía notamos un considerable descenso del componente Pica Tarapacá $(26,2 \%)$ y el radical aumento de los tipos formativos tardíos sobre todo de los pulidos $(37,8 \%)$, destacando los tipos QRP, CNP e incluso SNP de San Pedro de Atacama. Así, las cerámicas de los períodos Formativo Tardío e Intermedio Tardío aparecen asociadas en la mayoría de los contextos, pero según sus frecuencias relativas se confirma un dominio de cerámica del Intermedio Tardío hacia los niveles superiores del sitio, mientras que en conjuntos equivalentes aparecen hacia los niveles intermedios e inferiores. Estas observaciones fueron coincidentes con la de Mavrakis (1985); compartimos con él la idea de un primer momento con una predominancia de tipos alisados, engobados, pulidos y bruñidos, especialmente en las capas intermedias e inferiores; seguido por una segunda etapa con muy poca cerámica pulida y un considerable aumento de los alisados hacia la superficie, casi desapareciendo el tipo CNP. Dicho cambio para el autor habría ocurrido entre 600 y 800 d.C. (Mavrakis 1985:166), lo que a nuestro parecer y de manera muy semejante a como previamente lo propuso True (1980), habría dado paso al Intermedio Tardío y su alfarería monocroma, café y estriada, desarrollándose de manera plena a partir de 950 d.C. según un fechado radiocarbónico no calibrado. Dichas apreciaciones también fueron corroboradas por una fecha obtenida por nosotros de los niveles superiores de Caserones, correspondiente a 890-1.020 cal. d.C. (Uribe et al. 2007).

Con el propósito de actualizar y ampliar la muestra se excavaron otras cuatro unidades de $1 \mathrm{~m}^{2}$ en el sitio (aumentando finalmente a 21 unidades). En este caso se distinguieron hasta 11 estratos, además de algunos rasgos, pero donde se obtuvieron tan sólo 146 fragmentos de cerámica (poco más de 36 trozos como promedio por cuadrícula) ${ }^{8}$. Por lo tanto, al igual que el resto, el sitio también presentaría escasa cantidad de material, donde el 97,69\% se concentra en los niveles intermedios (Tabla 5). Prácticamente, más de $80 \%$ de la cerámica corresponde a tipos formativos (Figura 20), exclusivamente de Tarapacá y también compartidos con el Loa inferior (tipos LCA, QTC, QRP y CNP). Esta vez, el tipo más común es el QTC $(32,88 \%)$ que está en todos los recintos y en más del $54 \%$ de los estratos. Le acompañan muy de cerca el tipo LCA ? ${ }^{9}$ y el tipo QRP; ambos aparecen en casi todos los recintos, el primero en más del 59\% de sus estratos y el segundo en más del 40\%. Después se encuentran los tipos CNP y $\mathrm{PCH}$, los que también aparecen en casi todos los recintos pero en una proporción más acotada aunque equivalente de capas $(31,81 \%$ y $36,36 \%$, respectivamente). Por último, se detectó el tipo PGA en dos recintos y en no más del $13 \%$ de los niveles; a éste le sigue el tipo SNP que se identificó en un 
Tabla 5. Distribución estratigráfica de los tipos cerámicos de la muestra de Caserones 1 (Se enmarca en negro la principal concentración estratigráfica de los tipos QTC, QRP, CNP y SNP).

Stratigraphic distribution of ceramic types from the Caserones 1 sample (The primary stratigraphic concentration of the types QTC, QRP, CNP and SNP is framed in black).

\begin{tabular}{|c|c|c|c|c|c|c|c|c|c|c|c|c|}
\hline Capa & LCA & LCA? & $\mathrm{CNP}$ & QRP & QTC & QTC? & SNP & $\mathrm{PCH}$ & $\mathrm{PCH} ?$ & PGA & ERO & Total general \\
\hline 1 & & & & & 2 & & & & & & & 2 \\
\hline 2 & & 1 & & 2 & 1 & & & & & & & 4 \\
\hline $2 \mathrm{~A}$ & & & & & 1 & & & & & & & 1 \\
\hline $2 B$ & & & & & 1 & & & & & & & 1 \\
\hline 3 & & 2 & & & 2 & & & 1 & & & & 5 \\
\hline $3 \mathrm{~A}$ & & 1 & & & & & & & & & 2 & 3 \\
\hline $3 B$ & & 2 & 1 & & & & & & & & & 3 \\
\hline $3 \mathrm{~B} \mathrm{~W}$ & & 1 & & & 2 & & & & & & & 3 \\
\hline 4 & & 1 & & 3 & 2 & & & 1 & & & & 7 \\
\hline 4A Interior & 1 & 1 & & & 4 & & & & & & & 6 \\
\hline 4B Exterior & & & & 3 & & & & & & & & 3 \\
\hline 4B Interior & & & 1 & 5 & & & & & 1 & & & 7 \\
\hline $4 \mathrm{C}$ Interior & & & & 2 & & & & & & & & 2 \\
\hline $4 \mathrm{~W}$ & & 3 & & 1 & 3 & & & & & & & 7 \\
\hline 5 & & 3 & 3 & 5 & 5 & 5 & & 2 & & 4 & 2 & 29 \\
\hline 5 Exterior & & 3 & & & & & & & & & & 3 \\
\hline 6 & & 1 & 2 & 2 & 13 & & 1 & 1 & & 2 & 5 & 27 \\
\hline 7 & & 1 & & & & & & & 1 & & & 2 \\
\hline 8 & & 2 & 3 & & 1 & 1 & & & 2 & & & 9 \\
\hline $9 \mathrm{~A}$ & & & 1 & & & & & 3 & & & & 4 \\
\hline 9B & & & & 1 & & & & & & & & 1 \\
\hline 11 & & & 1 & & & & & & & & & 1 \\
\hline Total general & 1 & 22 & 12 & 24 & 37 & 6 & 1 & 8 & 4 & 6 & 9 & 130 \\
\hline
\end{tabular}

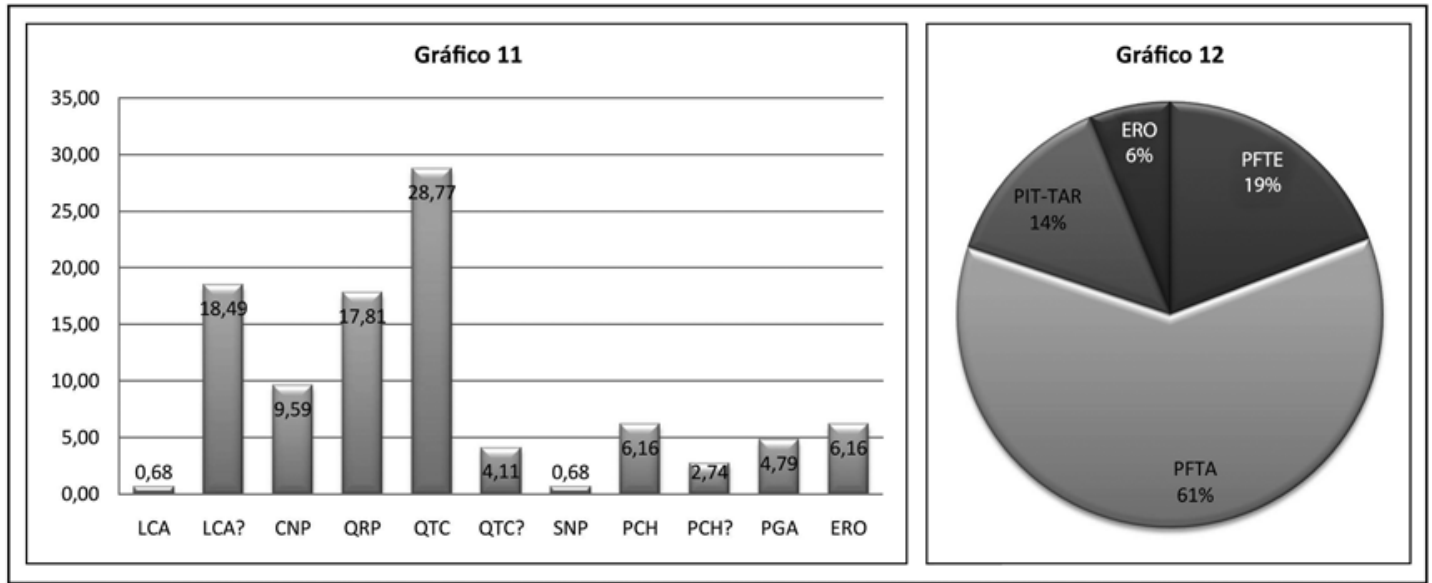

Figura 20. Gráficos 11 y 12: Tipos cerámicos y frecuencias relativas de la muestra de excavaciones de Caserones 1 (11). Componentes cerámicos y frecuencias relativas de la muestra de excavaciones de Caserones 1 (12).

Graphics 11 and 12: Ceramic types and relative frequencies of the Caserones 1 excavation samples (11). Ceramic components and relative frequencies of the Caserones 1 excavation samples (12). 
solo recinto y estrato. En tanto, los fragmentos erosionados alcanzan $6,16 \%$, sin registrarse restos de arcilla. Esto apoya lo inferido a partir de la muestra antes analizada, pues confirma la existencia de al menos dos momentos para la ocupación, referidas al Formativo y al Intermedio Tardío. Asimismo, se pueden establecer otras distinciones más significativas. Al revés de Pircas y sobre todo distinto a Guatacondo y Ramaditas, el material propio del Formativo Tardío de Caserones comprende más del $60 \%$ de la muestra, distinguiéndose con claridad de aquel del Formativo Temprano (con poco más de $19 \%)$. Por otra parte, si se considera la presencia conjunta de los tipos PCH y PGA que comprenden casi el $14 \%$ de la muestra, estaríamos frente a las expresiones típicas de inicios del Intermedio Tardío. Al revisar en detalle la estratigrafía (Tabla 5), se confirma que los tipos formativos son dominantes y se hallan ampliamente distribuidos a lo largo de toda la secuencia, en especial aquellos del Formativo Tardío y, en particular, el tipo QTC. En tanto, las evidencias más tardías del tipo PCH y PGA aparecen en proporciones menores y estratigráficamente más acotadas, pero también en gran parte de la secuencia. Por lo tanto, destaca una gran continuidad en la ocupación que impide una separación radical entre componentes; no obstante, junto con el predominio del material del Formativo Tardío, es posible apreciar que los tipos pulidos QRP, CNP y SNP tienden a concentrarse en los niveles más profundos de los estratos intermedios. De este modo, se confirman los planteamientos de Mavrakis (1985) y los nuestros sobre cierta diferenciación estratigráfica de dos importantes ocupaciones en Caserones. Además, por lo dudoso del tipo LCA y la circunscrita presencia de los tipos PCH y PGA, parece claro que si bien el uso del asentamiento pudo iniciarse hacia el Formativo Temprano, en realidad predominan las ocupaciones exclusivas del Formativo Tardío que se extenderían hasta inicios del Intermedio Tardío.

$\mathrm{Al}$ respecto, para la localidad de Caserones se cuenta con un conjunto significativo de fechas previas entre 150 y 780 d.C. (p.ej., Tartaglia 1980); las que, si bien no se encuentran todas calibradas, apoyan una intensa presencia durante el Formativo Tardío. Y, aparte de las dataciones que hemos dado a conocer para caracterizar el comienzo del Intermedio Tardío (Uribe et al. 2007), también contamos con otros fechados calibrados para el sitio que se remontan al 20-240 cal. d.C. y que sin duda refieren a la misma época (Méndez-Quirós y
Uribe 2010; Tabla 2). Paralelamente, los sitios Punta Blanca y Chomache de la costa de Iquique donde este mismo conjunto cerámico es importante, han entregado dataciones radio carbónicas entre 399560 y 650-770 cal. d.C. (Uribe 2009b). Igualmente, los sitios Quebrada de Tasma y Quebrada Ancha en la precordillera de Pica, cuentan con fechas entre 380-440 y 640-680 cal. d.C. para el mismo componente. Por otro lado, al contrario de Guatacondo y Ramaditas, para Caserones 1 sabemos de una sola fecha más antigua, de 350 a.C. (no calibrada), la que se adscribe al inicio de la ocupación e indica cierta presencia temprana (Tartaglia 1980), pero evidentemente con una menor intensidad que la del Formativo Tardío. Lo anterior es coincidente con otros análisis estrictamente cronológicos que, al calibrar las distintas dataciones para Tarapacá 40 y Caserones, sitúan la principal ocupación del asentamiento entre los años 200 al 900 d.C. (Oakland 2000; Southon et al. 1995).

\section{Sobre Cerámica, Funcionalidad y Asentamiento}

A partir del marco cronológico que proponemos, existiría un largo período Formativo dentro del cual se distinguiría una fase temprana y otra tardía que luego transitaría hacia el Intermedio Tardío. Esta secuencia se encontraría ejemplificada por los sitios Guatacondo, Ramaditas y Pircas para el Formativo Temprano; al mismo tiempo, Pircas junto a Caserones darían cuenta de una segunda fase, siendo este último el que representaría a cabalidad el Formativo Tardío y los inicios del Intermedio Tardío. No obstante, frente a esta interpretación excesivamente cronológica y que todavía requiere mayor apoyo de otras dataciones radiocarbónicas y por termoluminiscencia, nos interesa compartir ciertas consideraciones conductuales y funcionales (p.ej., Schiffer 1985) que permitirán profundizar el conocimiento sobre los asentamientos y grupos formativos de Tarapacá. De hecho, también esperamos que este ejercicio ayude a ir más allá de las relaciones temporales y poblacionales tan directas que hacemos, avanzando hacia una comprensión más sustantiva de las situaciones y/o prácticas a las que refiere la alfarería del Formativo. Por consiguiente, analizamos y exponemos ciertas características depositacionales y el comportamiento del material cerámico de acuerdo a cada uno de los sitios estudiados. 
En Guatacondo, el material recolectado en superficie apunta a un uso residencial caracterizado por una baja frecuencia de fragmentos, de tamaño reducido, con escasos indicadores de forma, prácticamente nulas huellas de uso y una restauración o remontado entre fragmentos que alcanza de $5,15 \%$ a $18,37 \%$ (Tabla 6). Esto indica que se trata de desechos primarios, es decir, pocos y pequeños trozos, varios de los cuales restauran, pero con mínimos indicadores de forma y uso; seguramente derivados de una limpieza sistemática de pisos domésticos que no constituyeron basureros ni evidencian un abandono repentino, sino programado. Tal situación, según hemos visto, es generalizada para el sitio y sería propia del Formativo Temprano conforme al predominio del tipo LCA. Lo anterior es confirmado por el material de las excavaciones y, aunque todavía es necesario aumentar la cobertura, también sería compartido con Ramaditas donde los pisos, de acuerdo a nuestros sondeos, tienden a aparecer completamente limpios ${ }^{10}$. Aquí los fragmentos son aún menos y aparecen concentrados en la superficie, los indicadores de forma son escuetos, se detectan mínimas huellas de uso (p.ej., hollín) y el tamaño también es pequeño. En ambos casos, la presencia de agujeros de reparación y la escasa cantidad cerámica evidencian una limitada producción alfarera con fines utilitarios como el almacenamiento y

Tabla 6. Frecuencias absolutas y relativas de los principales indicadores depositacionales por sitio, de acuerdo a su proveniencia de superficie y/o excavaciones (el porcentaje de cantidad es respecto al total de la muestra, correspondiente a 1.526 fragmentos). Absolute and relative frequencies of the principle depositional indicators by site, according to the surface and/or excavation provenience (the percent is in relation to the total sample size of 1,526 fragments).

\begin{tabular}{|c|c|c|c|c|c|c|c|c|}
\hline Guatacondo & 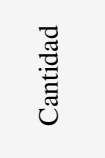 & 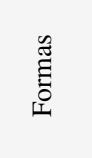 & 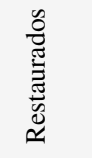 & $\begin{array}{l}\stackrel{\tilde{\Xi}}{\tilde{\Xi}} \\
\stackrel{\mathscr{D}}{D}\end{array}$ & 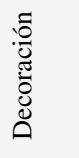 & 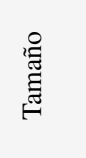 & 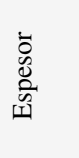 & \\
\hline Rec. Sup. & 136 & 5 & 7 & 0 & 0 & 33,28 & 6,52 & Prom \\
\hline$\%$ & 8,91 & 3,68 & 5,15 & 0,00 & 0,00 & 11,79 & 1,12 & Ds \\
\hline Excavaciones & 49 & 5 & 9 & 0 & 0 & 41,18 & 7,59 & Prom \\
\hline$\%$ & 3,21 & 10,20 & 18,37 & 0,00 & 0,00 & 24,66 & 1,94 & Ds \\
\hline Ramaditas & 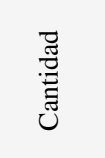 & 节 & 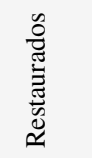 & $\begin{array}{l}\tilde{g} \\
\stackrel{\tilde{n}}{0} \\
\tilde{n}\end{array}$ & 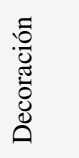 & 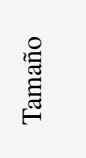 & 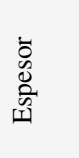 & \\
\hline Rec. Sup. & 38 & 4 & 2 & 1 & 0 & 67,00 & 6,25 & Prom \\
\hline$\%$ & 2,49 & 10,53 & 5,26 & 2,63 & 0,00 & 20,26 & 1,16 & Ds \\
\hline Pircas & 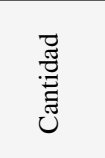 & 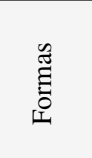 & 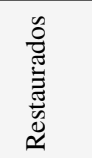 & $\begin{array}{l}\stackrel{0}{o} \\
\stackrel{\mathscr{J}}{0} \\
:\end{array}$ & 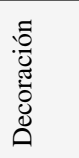 & 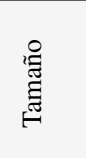 & 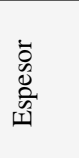 & \\
\hline Rec. Sup. & 962 & 100 & 63 & 8 & 4 & 52,56 & 7,13 & Prom \\
\hline$\%$ & 63,04 & 10,40 & 6,55 & 0,83 & 0,42 & 27,27 & 2,30 & Ds \\
\hline Excavaciones & 195 & 19 & 18 & 0 & 0 & 42,99 & 5,77 & Prom \\
\hline$\%$ & 12,77 & 9,74 & 9,23 & 0,00 & 0,00 & 29,25 & 1,77 & Ds \\
\hline Caserones & 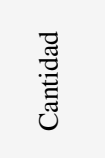 & 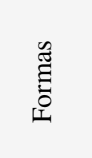 & 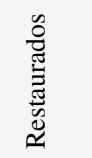 & $\begin{array}{l}\tilde{o} \\
\stackrel{0}{\tilde{D}} \\
\ddot{\omega}\end{array}$ & 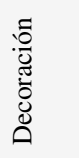 & 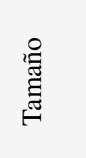 & $\begin{array}{l}\overrightarrow{0} \\
0 \\
0 \\
0 \\
0\end{array}$ & \\
\hline Excavaciones & 146 & 26 & 17 & 2 & 0 & 41,59 & 6,86 & Prom \\
\hline$\%$ & 9,56 & 17,81 & 11,64 & 1,37 & 0,00 & 26,34 & 2,38 & DS \\
\hline
\end{tabular}


transporte, pero no necesariamente dirigidos a la cocción de alimentos. Reiteramos, entonces, que existiría una acotada manufactura cerámica, un escaso empleo de vasijas con fines domésticos precisos y/u ocupaciones pasajeras que promovieron el uso alternado o temporal del asentamiento. De hecho, la notoria ausencia de contenedores usados como ollas y un énfasis en grandes pero sencillas piezas restringidas empleadas a modo de cántaros, denotan el interés por las prácticas de acopio y contención de líquidos con fines bastante específicos, lo que se ajustaría bien con una situación de alta movilidad y/u ocupación estacional.

En Pircas, el material recolectado en superficie también muestra una depositación de carácter residencial. Pero, esta vez caracterizada por una cantidad de cerámica algo mayor que en Guatacondo y Ramaditas, con trozos de dimensiones regulares que también superan los $7 \mathrm{~cm}$ de largo; a esto se suma una restaurabilidad del $6,55 \%$ al $9,23 \%$, bastantes indicadores de forma y claras huellas de uso, aparte de cerámica decorada más tardía (Tabla 6). Esto otra vez indica que se trata de desechos primarios, derivados de la limpieza de pisos domésticos; aunque por el leve aumento de la cantidad, tamaño y grado de restauración, así como por una mayor presencia de formas y uso, también se generaron algunas concentraciones a modo de pequeños basurales. Lo anterior es consistente con el comportamiento del material de las excavaciones, donde además estratigráficamente disminuye la variedad tipológica, la que ya no integra expresiones posteriores al Intermedio Tardío. Así, nos parece que la distinción cronológica realizada estaría relacionada con un cambio en el patrón de asentamiento y las actividades realizadas, siendo posible observar que se generarían más desechos secundarios, incluyendo hollín en el tipo LCA y su probable uso como ollas. En este sentido, aquí comenzarían a formarse basurales menores, lo que se debería a una mayor permanencia y/o una concentración de población considerable o en crecimiento, con áreas de actividad más formales.

No obstante, cabe recordar que la cantidad de alfarería todavía es poca, lo cual mantiene nuestra apreciación de una limitada producción cerámica, un escaso empleo de vasijas con fines domésticos acotados y/u ocupaciones pasajeras que promovieron el uso alternado o temporal del asentamiento. De todos modos, la presencia sería cada vez más estable y/o de un grupo mayor, donde la variedad tipológica se amplía a las clases cerámicas propias del Formativo Tardío, con vasijas más pequeñas aunque abundantes, de factura menos cuidada pero de conocimiento generalizado, las que aluden principalmente al servicio y consumo, aparte de las funciones de almacenamiento. A esto podríamos agregar que la producción de esta alfarería, que hemos conceptualizado como "expeditiva" frente a la del Formativo Temprano y del tipo LCA en particular (Uribe y Ayala 2004), sugiere de acuerdo a su heterogeneidad petrográfica, un acceso más extendido a la tecnología, una ampliación de su funcionalidad y/o una mayor cantidad de talleres para su elaboración. De hecho, esta clase de piezas son las que aparecen recurrentemente en los sitios funerarios del Formativo Tardío (p.ej., Tarapacá 40B y Pica-Quisma), donde existen otras actividades que adquieren relevancia en torno a estos asentamientos y que escapan a las labores productivas más corrientes. Asimismo, cabe recordar que esta cerámica es la que alcanza una gran distribución por la costa de Iquique, sobre todo en la desembocadura del Loa (Moragas 1995; Uribe 2009a), reiterando que se mantiene alta la movilidad pero también se intensifica y amplía su producción, acorde con una mayor estabilidad en los asentamientos donde la alfarería se elaboró, utilizó y/o fue distribuida con fines domésticos y funerarios.

En Caserones es elocuente que la muestra otra vez da cuenta de una ocupación residencial, esta vez caracterizada por una cantidad de cerámica mayor que en Guatacondo, Ramaditas y Pircas; a esto se suman los fragmentos remontados que alcanzan $11,64 \%$, y cierta presencia de formas y huellas de uso (Tabla 6). Nuevamente se trata de desechos primarios derivados de la limpieza de pisos domésticos; pero, si además consideramos que sólo son cuatro unidades de excavación, con un importante aumento de la cantidad, tamaño, restaurabilidad, indicadores de forma y uso, es indudable que se habrían generado depósitos más densos. Es decir, desechos secundarios a modo de pequeños basurales al interior de las construcciones, quizás recintos en desuso o empleo parcial. Esta situación no sería aplicable a la totalidad del sitio debido a la ocupación heterogénea que cronológicamente permitió, dentro de un continuo, segregar dos grandes momentos posibles de adscribir al Formativo Tardío e inicios del Intermedio Tardío. En este sentido, nos parece que la distinción cronológica realizada estaría relacionada con el cambio en el patrón de asentamiento 
que ya sugerimos para Pircas. Por consiguiente, concentrándonos en las ocupaciones formativas, en Caserones se aprecia una intensificación doméstica de la cerámica, se incrementa su uso como ollas, el tipo PCH desplazaría al tipo LCA prolongándose hacia el Intermedio Tardío y serían comunes los basurales menores al interior de los recintos; lo que, sin perder movilidad, se debería a una mayor permanencia y a la concentración de la población en un elaborado asentamiento con variadas labores residenciales y elocuente actividad pública (Adán et al. 2007; Vidal 2009).

\section{Palabras Finales}

Volviendo a la demanda planteada por Núñez en los años ochenta (1984a) y con la que iniciamos este artículo, creemos haber contribuido con una detallada monografía de una materialidad para la cual no existía un acabado y actualizado estudio, impidiendo contar con una sólida perspectiva para tan destacables asentamientos del Formativo regional. Los que en general se habían entendido contemporáneos o como parte de una secuencia todavía laxa y, para los cuales, los referentes más considerados habían sido la arquitectura, su textilería y restos funerarios (p.ej., Núñez 1982a; Adán et al. 2007; Oakland 2000). No obstante, la constante alusión a la alfarería y a casos específicos (Núñez y Moragas 1983; Mavrakis 1985; Rivera 1988-89), no podía dejarse de lado y requería este estudio, capaz de incluir y comparar los adelantos aldeanos ya observados. Por lo tanto, a partir y más allá de la secuencia planteada, nuestra impresión es que existirían al menos tres escenarios sociales distintos, diacrónicos y sincrónicos; cuyas poblaciones compartieron el espacio y una cultura material como la cerámica, pero que experimentaron cambios de manera paralela y particular, lo que permite alejarnos de una concepción única, lineal y homogeneizante del Formativo (Pauketat 2004:199-203).

Según hemos visto, es elocuente que estas poblaciones poseyeron un acabado conocimiento de la cerámica desde el primer milenio antes de nuestra era. Hasta ahora sin evidencia incuestionable que revele un ingreso externo, especialmente del altiplano (Ayala y Uribe 2003; Ayala et al. 2008); a la vez que delata una estrecha relación con la industria que aparece en la costa aledaña, tal cual fuera propuesto con anterioridad (Núñez 1969, 1970; Núñez y Santoro 2011; Uribe 2009a). En consecuencia, de acuerdo con la poca aunque consolidada cerámica producida (tipo LCA), se propone para el Formativo Temprano un asentamiento temporal e intermitente por parte de grupos humanos bien cohesionados de acuerdo a su habitus técnico (Dietler y Herbich 1998). Quienes, aun manteniendo una alta movilidad entre el interior y la costa, habrían habitado poblados de manera aglutinada y quizás estacional, motivados seguramente por la concentración de recursos en las quebradas de la Pampa del Tamarugal durante algunos momentos determinados del año (también planteado por True [1980]). Cuando se daba esta presencia, pareciera que la actividad era de escala colectiva, al menos por un considerable tamaño de las vasijas, su capacidad de almacenaje más que de cocina, sobre todo para un importante transporte de líquidos, acompañando una especial inversión arquitectónica que destaca en Guatacondo y Ramaditas. Así, junto con actividades productivas como la recolección y ciertos cultivos (p.ej., algarrobo y quínoa ${ }^{11}$ ) debieron aprovecharse las instancias de encuentro para desarrollar otras múltiples prácticas sociales como las festivas, evidentes en los arreglos de estos poblados y una inusitada infraestructura agrícola en desarrollo, pero sin mayor trascendencia hacia el Formativo Tardío (Adán et al. 2007; Martindale 2005; Rivera 2005).

Luego, a partir de algún momento del Formativo Temprano ciertos asentamientos de la pampa como Pircas verían intensificado su acceso, permanencia y/o el tamaño de los grupos que se reunían en ellos. Por lo tanto, la estabilidad habría sido más larga y la actividad de escala claramente colectiva de acuerdo a la mayor cantidad y diversidad de vasijas empleadas en su funcionamiento, así como por la amplitud y dispersión de poblados como éste. A partir de tal momento ya es indiscutible que las actividades productivas se desenvolvieron a la par de múltiples prácticas sociales y festivas como las que ejemplifican los cementerios cercanos (p.ej., Tarapacá 40) ${ }^{12}$; donde hasta ahora no hemos detectado con certeza la cerámica temprana del tipo LCA, pero sí la formativa tardía, en especial el tipo QTC y las variedades pulidas QRP. Tampoco podemos olvidar que otras expresiones ceremoniales donde aparece esta alfarería incluyen los típicos túmulos de la región (Agüero y Uribe 2008) y es muy probable que también tengan un vínculo con expresiones de arte rupestre que aparecen en esta época (Núñez 1984b). Más allá de si se trata de poblaciones distintas o no, lo que en esta oportunidad 
es imposible de abordar desde el estudio cerámico, lo cierto es que en Pircas los tipos tempranos y tardíos aparecen asociados estratigráficamente a partir de un momento específico, sugiriendo que algunos grupos del Formativo están experimentando una situación distinta a la de otros. De hecho, según las dataciones, es muy seguro que Guatacondo y Ramaditas sigan siendo contemporáneos por algún tiempo con Pircas; pero el proceso que se estaría detonando es distinto en este último, pues a diferencia de los anteriores continúa en el tiempo y llega a ser compartido con algunos sitios de la costa que muestran cierta inversión arquitectónica (p.ej., Caleta Huelén Alto [Uribe 2009a, 2009b]). Al respecto, asumimos por ahora que el paisaje seguiría siendo el mismo, razón por la cual apostamos a que lo que realmente está en proceso de transformación es la conceptualización de esas poblaciones respecto a su situación en el espacio. Esto es elocuente en la quebrada de Tarapacá, donde el acercamiento a los lugares más seguros de convergencia entre recursos de recolección, suelo y agua para cultivos (incluyendo el maíz), se convertiría en una variable no sólo experimental, sino claramente racionalizada, idealizada y extendida (Núñez 1979; Uribe y Adán 2009). De la misma manera, la tecnología cerámica pareciera extenderse y funcionar no sólo como un ortodoxo conocimiento ligado a un limitado segmento de la población, sino a la generalidad de sus comunidades; según queda claro en la heterogeneidad petrográfica de su elaboración y en su ampliación tanto morfológica como funcional, pudiéndose manufacturar en distintos talleres.

Sin duda, el patrón que comienza a configurarse a lo largo de la ocupación de Pircas se consolidaría en Caserones, considerando la densidad de los depósitos y la envergadura que adquiere con alrededor de 645 recintos y sus notables espacios públicos a modo de patios y plazas, todos encerrados por un imponente muro perimetral doble (Adán et al. 2007; Núñez 1982a; True 1980). En este marco, por ejemplo, aparecen verdaderos basurales con cerámica, crece aún más la diversidad, se definen áreas de actividad por su uso para cocina, lo que confirma que en el Formativo Tardío se generaliza una concentración de población y una intensificación económica y social notables en relación con el mismo territorio ancestralmente habitado; articulando recursos de recolección, agrícolas y costeros, destacando el maíz entre ellos (Magdalena García y Alejandra Vidal comunicación personal
2011). Además, porque junto con que esta cerámica $\mathrm{y}$ otras materialidades muebles aparezcan concentradas en varios puntos de la costa de Iquique, al igual que en Pica y Quillagua (Agüero et al. 2006; Moragas 1995; Uribe 2009a), lo están haciendo en directa relación con cementerios y túmulos de espacios atractivos y significativos que convergen concreta y estilísticamente hacia la quebrada de Tarapacá, constituyéndose un centro con la vigencia que tanto Guatacondo como Ramaditas no alcanzaron (Núñez 1979; Agüero y Uribe 2008). Como corolario, más allá de asumir toda esta situación como la simple expresión de un proceso de sedentarización circularmente adscrito al desarrollo agrícola del interior y la fijación al espacio por la sobreproducción de recursos eficientes en la costa (Núñez 2006), nos parece que más bien se trata de una relación diferente entre la sociedad, la tecnología y el territorio. Pues, de hecho, asentamientos como éste no reflejan una ocupación totalmente permanente (True 1980) y la movilidad nunca se reduce por completo ni hay evidencia total de su traspaso a especialistas permanentes como muchas veces se concibe a las caravanas centro sur andinas (Núñez 1984b; Núñez y Dillehay 1995[1979]). De acuerdo con nuestra propuesta, la presencia de cántaros y vasos como los que ahora aparecen recurrentemente representados en estos contextos arqueológicos pareciera no ser azarosa, sino más bien un ejemplo consciente de la racionalización de las conductas públicas y festivas; que, a través del tiempo, con sus bebidas y comidas a favor del encuentro social y la práctica económica resultan tan particulares de los Andes y que, con antelación a esos clásicos modelos de verticalidad, son tan prioritarias como adecuadas para la articulación humana del desierto tarapaqueño.

Agradecimientos: Este trabajo es resultado del proyecto FONDECYT 1080458. Agradecemos a los coinvestigadores Leonor Adán, Carolina Agüero, Antonio Maldonado y Simón Urbina, así como a todo el equipo de apoyo que ha participado comprometidamente con este proyecto. De igual modo, a Paulina Chávez por las ilustraciones como también a los evaluadores y sus valiosos comentarios que contribuyen sobremanera a mejorar la calidad de nuestro trabajo. Finalmente, gracias a los distintos estudiantes por su gran apoyo y a las comunidades de Tarapacá por la comprensión a la investigación científica. 


\section{Referencias Citadas}

Adán, L., S. Urbina y M. Uribe 2007. Arquitectura pública y doméstica en las quebradas de Tarapacá: asentamiento y dinámica social en el Norte Grande de Chile. En Taller Procesos Sociales Prehispánicos en los Andes Meridionales, editado por A. Nielsen, C. Rivolta, P. Mercolli, M. Vásquez y V. Seldes, pp. 183-206. Editorial Brujas, Córdoba.

Agüero, C., P. Ayala, M. Uribe, C. Carrasco y B. Cases 2006. El período Formativo desde Quillagua, Loa Inferior (norte de Chile). En Esferas de Interacción Prehistóricas y Fronteras Nacionales Modernas: los Andes Sur Centrales, editado por H. Lechtman, pp. 449-502. IEP-IAR, Lima.

Agüero, C. y M. Uribe 2008. Tombs and tumuli on the coast and pampa of Tarapacá: Explaining the Formative period in northern Chile. Ponencia presentada en Segundo Congreso de la Red Europea de Estudios Amerindios-Ritual Americas, Lovaina la Nueva, Bélgica.

Agüero, C., M. Uribe, P. Ayala, B. Cases y C. Carrasco 2001. Ceremonialismo del período Formativo en Quillagua, Norte Grande de Chile. Boletín de la Sociedad Chilena de Arqueología 32:24-34.

Aufderheide, A., M. Kelley, M. Rivera, L. Gray, L. Tieszen, E. Iversen, R. Krouse y A. Carevic 1994. Contributions of chemical dietary reconstruction to the assessment of adaptation by ancient highland immigrants (Alto Ramírez) to coastal conditions at Pisagua, North Chile. Journal of Archaeological Science 21:515-524.

Ayala, P., C. Carrasco y M. Uribe 2008. Alfarería y líticos Wankarani: caracterización y vínculos con el Norte Grande de Chile. En Arqueología de las Tierras Altas, Valles Interandinos y Tierras Bajas de Bolivia. Memorias del I Congreso de Arqueología de Bolivia, editado por C. Rivera, pp. 99-114. Instituto de Investigaciones Antropológicas y Arqueológicas, Universidad Mayor de San Andrés, PIEB, ASDI-SAREC, La Paz.

Ayala, P. y M. Uribe 2003. La cerámica Wankarani y una primera aproximación a su relación con el período Formativo del Norte Grande de Chile. Textos Antropológicos 14:7-30.

Bird, J. 1943. Excavations in Northern Chile. Anthropological Papers of the American Museum of Natural History XXXVIII(4), Nueva York.

Dauelsberg, P. 1985. Faldas del Morro: fase cultural agroalfarera temprana. Chungara 4:7-44.

Dietler, M. e I. Herbich 1998. Habitus, techniques, style: An integrated approach to the social understanding of material culture and boundaries. En The Archaeology of Social Boundaries, editado por M. Stark, pp. 233-263. Smithsonian Institution Press, Washington.

Gallardo, F., L. Cornejo, R. Sánchez, B. Cases, A. Román y A. Deza 1991. Una aproximación a la cronología y el asentamiento en el oasis de Quillagua (río Loa, II Región). Actas XII Congreso Nacional de Arqueología Chilena, Vol. 4, pp. 41-60. Temuco.

Heaton, T.J, P.G. Blackwell y C.E. Buck 2009. A Bayesian approach to the estimation of radiocarbon calibration curves: the IntCal09 methodology. Radiocarbon 51:1151-1164.
Kautz, R., T. Delaca y D. True 1980. Constituent analysis of prehistoric pottery using X-ray dispersive analysis: Caserones plainware. Estudios Arqueológicos 5:21-27.

Latcham, R. 1938. Arqueología de la Región Atacameña. Prensas de la Universidad de Chile, Santiago.

Lumbreras, L. 2006. Un formativo sin cerámica y cerámica preformativa. Estudios Atacameños 32:11-34.

Martindale, A. 2005. A method for analyzing vernacular architecture: A case study from the Ramaditas site, Chile. En Arqueología del Desierto de Atacama. La Etapa Formativa en el Área de Ramaditas/Guatacondo, editado por M. Rivera, pp. 133-172. Universidad Bolivariana, Santiago.

Mavrakis, R. 1985. Análisis Tipológico Morfológico de la Cerámica de Caserones ( $1^{a}$ Región, Chile). Memoria para optar al título de Arqueólogo, Universidad del Norte, Antofagasta.

Meighan, C. 1980. The archaeology of Guatacondo, Chile. En Prehistoric Trails of Atacama: Archaeology of Northern Chile, editado por C.W. Meighan y D.L. True, pp. 93-133. Monumenta Archaeologica 7, The Institute of Archaeology, University of California, Los Angeles.

Méndez-Quirós, P. y M. Uribe 2010. Análisis estratigráfico y cronología del complejo cultural Pica-Tarapacá (950-1450 d.C.). Actas XVII Congreso Nacional de Arqueología Chilena Tomo 1, pp. 47-57. Universidad Austral de Chile, Valdivia.

Moragas, C. 1982. Túmulos funerarios de la costa sur de Tocopilla (Cobija), II región. Chungara 9:152-173.

. _ _ 1995. Desarrollo de las comunidades prehispánicas del litoral Iquique-desembocadura río Loa. Actas XIII Congreso Nacional de Arqueología Chilena Hombre y Desierto. Una Perspectiva Cultural, Tomo 1:65-80.

Mostny, G. 1970. La subárea arqueológica de Guatacondo. Boletín del Museo Nacional de Historia Natural XXIX: 271-287.

Muñoz, I. 1983. La fase Alto Ramírez del extremo norte de Chile (valle-costa). Documentos de Trabajo 3:3-42.

- _ _ 1989. El período Formativo en el Norte Grande (1000 a.C. a 500 d.C.). En Culturas de Chile. Prehistoria, desde sus Orígenes hasta los Albores de la Conquista, editado por J. Hidalgo, V. Schiappacasse, H. Niemeyer, C. Aldunate e I. Solimano, pp. 107128. Editorial Andrés Bello, Santiago.

- _ _ 2004. El período Formativo en los valles del norte de Chile y sur de Perú: Nuevas evidencias y comentarios. Chungara Revista de Antropología Chilena 36 número especial, Tomo 1, pp. 213-225.

_ _ _ 2005. Las poblaciones de los valles costeros del área Centro Sur Andina durante los inicios del proceso aldeano (1000 a.C. a 200 d.C.). En Arqueología del Desierto de Atacama. La Etapa Formativa en el Área de Ramaditas/Guatacondo, editado por M. Rivera, pp. 231-258. Universidad Bolivariana, Santiago.

Muñoz, I., R. Rocha y J. Chacama 1991. Camarones 15. Asentamiento de pescadores correspondiente al Arcaico y Formativo (extremo norte de Chile). Actas del XI Congreso Nacional de Arqueología Chilena, Vol. 2, pp. 1-24. Museo Nacional de Historia Natural, Santiago. 
Núñez, L. 1965. Desarrollo cultural prehispánico del norte de Chile. Estudios Arqueológicos 1:37-85.

- _ _ 1966. Caserones-1, una aldea prehispánica del norte de Chile. Estudios Arqueológicos 2:25-29.

- _ _ 1967-68. Figurinas tempranas del norte de Chile (Provincia de Tarapacá). Estudios Arqueológicos 3-4:85-105.

- _ _ 1969. El primer fechado radiocarbónico del complejo Faldas del Morro en el sitio Tarapacá-40 y algunas discusiones básicas. Actas del V Congreso Nacional de Arqueología Chilena, pp. 47-58. Museo Arqueológico de La Serena, La Serena.

_. _ _ 1970. Algunos problemas del estudio del Complejo arqueológico Faldas del Morro, norte de Chile. Abhandlungen und Berichte de Staatlichen Museums für Volkerkunde, AkademieVerlag Berlin, Band 31:79-109.

_ _ _ 1971. Secuencia y cambio en los asentamientos humanos de la desembocadura del río Loa en el norte de Chile. Boletín de la Universidad de Chile 112:3-25.

_. _ . 1979. Emergencia y desintegración de la sociedad tarapaqueña: riqueza y pobreza de una quebrada del norte de Chile. Atenea 439:163-213.

- _ - 1982a. Temprana emergencia de sedentarismo en el desierto chileno. Proyecto Caserones. Chungara 9:80-122.

_ _ _ 1982b. Pircas: Ocupación temprana en el norte de Chile. Gaceta Arqueológica Andina 11:8-12.

_. _ _ 1984a. El asentamiento Pircas: Nuevas evidencias de tempranas ocupaciones agrarias en el norte de Chile. Estudios Atacameños 7:152-177.

_ - _ 1984b. Tráfico de Complementariedad de Recursos entre las Tierras Altas y el Pacífico en el Área Centro Sur Andina. Tesis para optar al grado de Doctor en Arqueología, Universidad de Tokio, Tokio.

- _ - 2006. Asentamientos formativos complejos en el centro-sur andino: Cuando la periferia se constituye en núcleo. Boletín de Arqueología PUCP 10:321-356.

Núñez, L. y T. Dillehay 1995 [1979]. Movilidad giratoria, Armonía Social y Desarrollo en los Andes Meridionales. Patrones de Tráfico e Interacción Económica. Ensayo. Universidad del Norte, Antofagasta.

Núñez, L. y C. Moragas 1983. Cerámica temprana en Cáñamo (costa desértica del norte de Chile): análisis y evaluación regional. Chungara 11:31-61.

Núñez, L. y C.M. Santoro 2011. El tránsito arcaico-formativo en la circumpuna y valles occidentales del centro sur andino: hacia los cambios "neolíticos". Chungara Revista de Antropología Chilena 43:487-530.

Oakland, A. 2000. Andean textiles from village and cemetery: Caserones in the Tarapacá valley, northern Chile. En Beyond Cloth and Cordage, Archaeological Textile Research in the Americas, editado por P. Drooker e I. Webster, pp. 229-251. The University of Utah Press, Salt Lake City.

Oeschger, H., U. Siengenthaler, U. Schotterer y A. Gugelmann 1975. A box diffusion model to study the carbon dioxide exchange in nature. Tellus 27:168-192.

Pauketat, T. 2004. Archaeology without alternatives. Anthropological Theory 4:199-203.
Reimer, P.J, M.G.L. Baillie, E. Bard, A. Bayliss, J.W. Beck, P.G. Blackwell, C. Bronk Ramsey, C.E. Buck, G.S. Burr, R.L. Edwards, M. Friedrich, P.M. Grootes, T.P. Guilderson, I. Hajdas, T.J. Heaton, A.G. Hogg, K.A. Hughen, K.F. Kaiser, B. Kromer, F.G. McCormac, S.W. Manning, R.W. Reimer, D.A. Richards, J.R. Southon, S. Talamo, C.S.M. Turney, J. van der Plicht y C.E. Weyhenmeyer 2009. IntCal09 and Marine09 radiocarbon age calibration curves, 0-50,000 years cal BP. Radiocarbon 51:1111-1150.

Rivera, M. 1988-89. Cerámicas tempranas de la costa norte de Chile. Paleoetnológica 5:165-172.

_ _ _ 1994. Hacia la complejidad social y política: El desarrollo Alto Ramírez del norte de Chile. Diálogo Andino 13:9-36.

_ _ _ 2002. Historias del Desierto. Arqueología del norte de Chile. Editorial del Norte, La Serena.

Rivera, M. (ed.) 2005. Arqueología del Desierto de Atacama. La Etapa Formativa en el Área de Ramaditas/Guatacondo. Universidad Bolivariana, Santiago.

Rivera, M., D. Shea, A. Carevic y G. Graffam 1995-1996. En torno a los orígenes de las sociedades complejas andinas: excavaciones en Ramaditas, una aldea formativa del desierto de Atacama, Chile. Diálogo Andino 14-15:205-239.

Sanhueza, J. 2005. Un cementerio del período Formativo en el oasis de Pica (desierto de Tarapacá). Boletín de la Sociedad Chilena de Arqueología 38:31-43.

Santoro, C. 1980. Fase Azapa: transición del Arcaico al desarrollo agrario inicial en los valles bajos de Arica. Chungara 6:46-56.

_ _ _ 1981. Formativo Temprano en el extremo norte de Chile. Chungara 8:33-62.

_ _ _ 2000. El Formativo en la región de valles occidentales del área Centro Sur Andina (sur Perú-norte de Chile). En Formativo Sudamericano, editado por P. Lederberger-Crespo, pp. 243-254. Ediciones Abya-Ayala, Quito.

Schaedel, R. y C. Munizaga 1957. Arqueología Chilena: Contribuciones al Estudio de la Región Comprendida entre Arica y La Serena. Centro de Estudios Antropológicos, Universidad de Chile, Santiago.

Schiffer, M. 1985. Formation Processes of the Archaeological Record. University of New Mexico Press, Albuquerque.

Sinclaire, C. 2004. Prehistoria del período Formativo en la cuenca alta del río Salado. Actas XV Congreso Nacional de Arqueología Chilena. Chungara Revista de Antropología Chilena Tomo 2:619-639.

Sinclaire, C., M. Uribe, P. Ayala y J. González 1998. La alfarería del período Formativo en la región del Loa Superior: sistematización y tipología. Contribución Arqueológica 5:285-314.

Southon, J., A. Oakland y D. True 1995. A comparison of marine and terrestrial radiocarbon ages from northern Chile. Radiocarbon 37:389-393.

Spahni, J.C. 1967. Recherches archéologiques a l'embochure du Rio Loa (côte du Pacifique Chili). Journal de la Société des Americanistes 56:179-239.

Stuiver, M. y T.F. Braziunas 1993. Modeling atmospheric $14 \mathrm{C}$ influences and $14 \mathrm{C}$ ages of marine samples to $10,000 \mathrm{BC}$. Radiocarbon 35:137-189. 
Tartaglia, L. 1980. A revised C-14 chronology for northern Chile. En Prehistoric Trails of Atacama: Archaeology of Northern Chile, editado por C.W. Meighan y D.L. True, pp. 5-22. Monumenta Archaeologica 7, The Institute of Archaeology, University of California, Los Angeles.

True, D. 1980. Archaeological investigations in northern Chile: Caserones. En Prehistoric Trails of Atacama: Archaeology of Northern Chile, editado por C.W. Meighan y D.L. True, pp. 139178. Monumenta Archaeologica 7, The Institute of Archaeology, University of California, Los Angeles.

True, D. y L. Núñez 1971. Modeled anthropomorphic figurines from northern Chile. Ñawpa Pacha 9:65-68.

Uhle, M. 1922. Fundamentos Étnicos y Arqueología de Arica y Tacna. Universidad Central, Quito.

Uribe, M. 2006. Sobre cerámica, su origen y complejidad social en los Andes del desierto de Atacama. En Esferas de Interacción Prehistóricas y Fronteras Nacionales Modernas: los Andes Sur Centrales, editado por H. Lechtman, pp. 449-502. IEP-IAR, Lima.

_ _ _ 2009a. El período Formativo de Tarapacá y su cerámica: Avances sobre complejidad social en la costa del Norte Grande de Chile (900 a.C.-800 d.C.). Estudios Atacameños 37:5-27.

_ _ _ 2009b. El período Formativo en Tarapacá (norte de Chile) y nuevas posibilidades para una arqueología social latinoamericana. Ponencia presentada en $53^{\circ}$ Congreso Internacional de Americanistas, Universidad Iberoamericana, México DF.

- - _ 2010. Cerámica y complejidad social en la quebrada de Tarapacá: avances sobre el período Formativo y Horizonte Medio (norte de Chile). Actas del XVII Congreso Nacional de Arqueología Argentina Tomo I, pp. 145-150. Universidad Nacional de Cuyo, Mendoza.

Uribe, M. y L. Adán 2009. Evolución, neolítico, Formativo y complejidad: pensando el cambio desde Tarapacá (900 a.C.-800 d.C.). Ponencia presentada en XVIII Congreso Nacional de Arqueología Chilena, Museo de Historia Natural, Valparaíso.

Uribe, M. y P. Ayala 2004. La alfarería de Quillagua en el contexto formativo del Norte Grande de Chile (1000 a.C.-500 d.C.). Chungara Revista de Antropología Chilena 36 número especial, Tomo II, pp. 585-597.

Uribe, M., L. Sanhueza y F. Bahamondes 2007. La cerámica prehispánica tardía de Tarapacá, sus valles interiores y costa desértica, norte de Chile (ca. 900-1450 d.C.): una propuesta tipológica y cronológica. Chungara Revista de Antropología Chilena 39:143-170.

Vidal, E. 2009. Etnoarqueología de la fiesta andina: El caso de la región cultural de Tarapacá. Ponencia presentada en XVIII Congreso Nacional de Arqueología Chilena, Museo de Historia Natural, Valparaíso.

\section{Notas}

1 Si bien una buena parte de los túmulos se concentra cerca de zonas de desembocadura (p.ej., Camarones, Tana-Tiliviche y Loa), gracias a nuestras prospecciones sistemáticas, hoy también sabemos que en el litoral de Iquique las mismas manifestaciones adquieren una distribución más amplia (Ajata y Méndez-Quirós 2009). Por otra parte, la existencia de túmulos ya ha sido constatada en otras zonas intermedias del interior como en Quillagua (Agüero et al. 1995, 2001, 2006), discutiendo aún más un vínculo tan directo entre la costa y el altiplano.

2 Se emplearon cuatro ejemplares provenientes de San Pedro de Atacama como muestras de control, aunque descontextualizadas, correspondientes a los tipos negro pulido y rojo pulido inciso, donados por el Museo Nacional de Historia Natural de Santiago (Kautz et al. 1980).

3 Las mismas también se registran en Caserones y Tarapacá 40 (Núñez 1967-68; True 1980).

4 El análisis petrográfico de cortes delgados o transparentes fue realizado por la geóloga Dra. Marcia Muñoz, perteneciente al Departamento de Geología de la Facultad de Ciencias Físicas y Matemáticas de la Universidad de Chile.

5 Munsell Soil Color Charts.

6 En este punto es necesario precisar que en la región aún no se registra la presencia de una cerámica con antiplástico o desgrasante predominantemente orgánico en su pasta (concha y/o vegetales molidos), aspecto clave que define a la alfarería Faldas del Morro y Azapa de los Valles Occidentales de Arica y que caracterizan al Formativo Temprano de la costa que abarca desde el extremo sur del Perú hasta la desembocadura del río Camarones (Dauelsberg 1985; Muñoz 1989, 2004, 2005; Muñoz et al. 1991; Santoro 1980, 1981, 2000).
7 Específicamente, el inicio del Intermedio Tardío se reconoce por la aparición conjunta de los tipos Pica Charcollo, Pica Gris Alisado y Pica Chiza, generalmente asociados a tipos atacameños (Aiquina y Dupont) de la misma época y en ausencia de los tipos formativos de Tarapacá (Uribe 2010; Uribe et al. 2007).

8 De acuerdo a la muestra anterior se recuperaron un promedio de 57 fragmentos por cuadrícula excavada.

9 En este caso los ejemplares del tipo LCA son más dudosos, ya que no aparecen con tanta claridad los bordes en coma que lo caracterizan en Guatacondo, Ramaditas y Pircas. De este modo, los segregamos más bien por su tratamiento de superficie alisado y ausencia de las estrías o brochado que son propios del tipo $\mathrm{PCH}$. No obstante, puede tratarse de fragmentos de este último tipo donde las estrías no son tan marcadas o de una expresión transicional entre ambos, difícil de discriminar porque a simple vista las pastas y formas son muy semejantes.

10 Rivera (1995-96:215) documenta sólo 29 fragmentos obtenidos en la excavación completa del recinto 1 (en nuestro caso 3), correspondiente a una estructura de $100 \mathrm{~m}^{2}$ con un depósito que alcanza los $1.80 \mathrm{~m}$ de profundidad, lo cual implica una ínfima densidad cerámica de 0,0002 fragmentos por litro de sedimento de un total de $180 \mathrm{~m}^{3}$. Por otra parte, la existencia de una vasija entera y cinco figurillas incompletas de la misma estructura, es indicativo de desechos producidos por el abandono de la construcción. Lo anterior demuestra irrefutablemente la total limpieza de los pisos y ejemplifica el escaso, específico o especial empleo de la alfarería durante esta época, sobre todo por esta asociación entre contenedores y estatuillas. 
11 Magdalena García y Alejandra Vidal comunicación personal (2011), quienes han realizado los estudios arqueobotánicos de estos sitios en el marco de nuestro proyecto de investigación.
12 Creemos que aquí también se podrían incluir los cementerios Pircas 2 y 6 (Núñez 1982b), sin embargo, la información publicada es muy escueta y actualmente no existe acceso a la colección obtenida en estos sitios. 
